\title{
Does IS0 9001 quality management system support product innovation? An analysis from the sociotechnical systems theory
}

\author{
Younès El Manzani \\ Department of Management, Faculty of Legal, Economic and Social Sciences, \\ Cadi Ayyad University, Marrakesh, Morocco and \\ Jean Moulin University Lyon 3, Lyon, France \\ Mohamed Larbi Sidmou \\ Department of Management, Faculty of Legal, Economic and Social Sciences, \\ Cadi Ayyad University, Marrakesh, Morocco, and \\ Jean-jack Cegarra \\ Department of Management, Jean Moulin University Lyon 3, Lyon, France
}

\begin{abstract}
Purpose - Building on the sociotechnical systems theory (STS), the purpose of this paper is to investigate the direct impacts of the social and technical QMs (ISO 9001) practices on both incremental and radical product innovation and the direct relationships relaying QMs (ISO 9001) as a sociotechnical system with incremental and radical product innovation.

Design/methodology/approach - The paper opted for a survey instrument to collect quantitative data from 82 Moroccan certified ISO 9001 firm. A partial least squares structural equation modeling (PLS-SEM) was used to test the research hypotheses.

Findings - Results show that the social and technical QMs (ISO 9001) practices do not have a significant relationship with incremental and radical product innovation when they are taken in isolation. However, when ranged together to constitute a whole sociotechnical system of QMs (ISO 9001), QMs (ISO 9001) prove to have a strong positive and significant impact on incremental product innovation and a weak positive and significant impact on radical product innovation.

Research limitations/implications - Because of the small sample size that might weaken the significance of the results and the use of cross-sectional data, this research may lack a large statistical generalizability vis-à-vis the analytical generalization.

Practical implications - The results provide useful implications for managers, suggesting that in order to develop their product innovation, they must ensure that both QMs (ISO 9001) social and technical practices achieve a high level of integration without allowing some quality practices to take over.

Originality/value - Based on the STS, this study is the first to focus primarily on the role of the multi-dimensional structure of QMs (ISO 9001), i.e. social and technical practices, in incremental and radical product innovation.
\end{abstract}

Keywords ISO 9001, Morocco, Quality management system, Incremental product innovation,

Radical product innovation, Sociotechnical systems theory (STS)

Paper type Research paper

\section{Introduction}

In today's aggressive global competition, firms are obliged to improve quality and promote innovation to create and safeguard their sustainable competitive advantage at the same time (Cho and Pucik, 2005; Pekovic and Galia, 2009; Tushman and Nadler, 1986). However, a traditional view considers that there is a trade-off between quality and innovation to the extent that the increase of one leads to deteriorating the other, so firms must make an

Published in International Journal of Quality \& Reliability Managemen DOI 10.1108/IJQRM-09-2017-0174 
exclusive choice between quality and innovation (Flynn, 1994; Prajogo and Sohal, 2003). Conversely, the modern view rejects this idea and suggests that quality and innovation can coexist together in a cumulative improvement model, and firms that achieve excellence in quality are expected to also excel in innovation (Prajogo and Sohal, 2003; Zeng et al., 2015). According to Nowak (1997, p. 132) "Division of quality and innovation is, to some substantial extent, largely theoretical, not practical. In practice, because of self-reinforcing and dual-direction character of the impact quality management and innovation have on one another, firms seek quality through innovation or innovate through quality improvement." Thus, quality and innovation are two necessary business orientations that complement each other to raise performance and cannot be mutually exclusive, as McAdam et al. (1998, p. 140) said, "while quality is doing things better, innovation is doing things differently."

Over the past two decades, the quality and innovation relationship has generated widespread attention in the management literature. A review of the current studies reveals that a large body of the literature has mainly considered the role of the total quality management (TQM) in product innovation. However, less interest was presented in the quality management system QMs (ISO 9001) in the context of innovation. The limited number of studies that have studied the impact of QMs (ISO 9001) on product innovation show controversial results. On the one hand, some studies report that ISO 9001 positively influences product innovation (Kafetzopoulos et al., 2013, 2015; Pekovic and Galia, 2009; Refaie et al., 2011; Wu and Chen, 2011), since it has a set of elements that can foster innovation. While others found that QMs (ISO 9001) is negatively related to product innovation (Magd and Curry, 2003; Naveh and Erez, 2004; Terziovski and Guerrero, 2014; Wei, 2010) due to some of its components which are designed to eradicate waste and reduce variations which are inharmonious with innovation. Between the two streams there are studies that found no significant relationship between QMs (ISO 9001) and some product innovation aspects (Al-Refaie et al., 2012; Arauz and Suzuki, 2004; Bayo-Moriones et al., 2011; Delić et al., 2014; Huarng, 1998; Huo et al., 2014; Magd et al., 2003; Mangiarotti and Riillo, 2014; Pivka and Ursic, 2002; Yahya and Goh, 2001; Ziegler, 2015).

A close analysis of these studies reports a rigorous comparison between their contradictory results is difficult to carry out given the different samples, analysis methods and measurement used, though a major potential explanation of these results may be the neglected multidimensional aspects of quality management and innovation. Several authors have treated QMs (ISO 9001) and product innovation as one-dimensional variables without taking into consideration the different QMs (ISO 9001) practices and the types of product innovation in a single analysis. Hence, the multidimensional view of quality and innovation can be a promising approach to clear up the ongoing debate about quality management and innovation (Zeng et al., 2015). Abrunhosa and Moura E Sá (2008) state that it is difficult to generalize the inclusive impact of $\mathrm{QM}$ on innovation due to the complexity of $\mathrm{QM}$ that encompasses dissimilar components, and consequently can give rise to conflicting results when linked to innovation. Therefore, the relationship between QMs (ISO 9001) practices and product innovation is still unclear and the literature fails to precisely answer the question about the impact of QMs (ISO 9001) on product innovation.

The particularity of our study is that it follows the "brave" studies, in the sense of Davis et al. (2014), that extend the sociotechnical systems theory (STS) (Trist and Bamforth, 1951) and apply its core ideas to new management domains, besides the traditional focus on new technologies, or new types of systems that involve both social and technical components (Eason, 2014). Davis et al. (2014, p. 171, 172) argued, "[...] the use of socio-technical thinking to new areas may help address significant contemporary challenges offering opportunities for theoretical development [...]. We believe the focus of socio-technical systems research to-date has been too narrow and that there are new contexts and problems that could benefit substantially from sociotechnical systems thinking." Otherwise, some authors have used the 
STS in the field of quality management, particularly TQM (e.g. Carson and Stewart, 1996; Cua et al., 2001; Manz and Stewart, 1997; Zu, 2009), but, to the best of our knowledge, no single research has explored the consequences of social and technical practices of QMs (ISO 9001) in terms of product innovation.

Based on the STS, the aim of this study is to empirically test a conceptual framework of the relationship between QMs (ISO 9001) and product innovation. Our study seeks to contribute to a need in the literature by answering the question: How can QMs (ISO 9001) affect product innovation? First, we examine the direct impacts of the social and technical QMs (ISO 9001) practices on both incremental and radical product innovation. Then, we explore the direct relationships of QMs (ISO 9001) as a sociotechnical system with incremental and radical product innovation. To do so, the partial least square structural equation modeling (PLS-SEM) method was employed to analyze data drawn from 82 Moroccan certified ISO 9001 firm. The results emphasize that when the social and technical QMs (ISO 9001) practices are taken in isolation, they do not show any significant relationship with incremental and radical product innovation. Yet, when ranged together to constitute a whole sociotechnical system of QMs (ISO 9001), we noticed a positive and significant impact on both incremental and radical product innovation. This impact is remarkably stronger for incremental product innovation and weak for radical product innovation.

The remainder of this paper is organized as follows. The first section provides a literature review and establishes the hypothesis of our conceptual research model. The second describes the study sample and the data collection procedure. Third, we present the results of the estimation of the measurement and structural models. Finally, the paper concludes with a discussion of the findings, theoretical and managerial implications and gives limitations and suggestions for future research.

\section{Theoretical background and hypotheses}

\subsection{The social and technical practices of the quality management system (ISO 9001)}

Since the 1950s, researchers and managers have recognized that the technical and social organizational factors interact to influence the firm's performance. The rationale is that organizations are made up of people using tools, techniques and knowledge to produce products/services valued by customers who are part of the firm's external environment (Griffith and Dougherty, 2001). Inspired by the open systems theory (von Bertalanffy, 1969), this new standpoint came to criticize the technological determinism (Katz and Kahn, 1978) and to give birth to the STS that provides critical perspectives for understanding the relationships between the psychological, socio-psychological and sociological conditions of individuals, technology and organizational outcomes (von Bertalanffy, 1969). The STS goes beyond the technological determinism by considering the organization as a working system with two interdependent subsystems, the social system and the technical system (Manz and Stewart, 1997). The social system focuses on the relationships between people, their attitudes, skills and values, While The technical system handles the processes, tasks, and technology needed to transform inputs such as raw materials to outputs such as products (Bostrom and Heinen, 1977a, b). Given that work systems produce both physical products and social/psychological outputs (Appelbaum, 1997), the objective of the STS is to achieve a joint, balanced and synergistic optimization between the technical requirements of the organization and the needs and values of its members so that these two parties produce positive results (Bostrom and Heinen, 1977a, b; Griffith et al., 1998).

The QM and STS are broadly recognized as two utilized work design strategies (Manz and Stewart, 1997) that are connected due to some convergences between their theoretical frameworks. Shani and Mitki (1996) identified some shared distinct similarities between STS and QM (TQM): the two perspectives focus on the entire system; they need a strategic 
decision that entails major financial and resource investment and commitment; both focus on customers and improvement; their change process is substantially based on the organizational learning and; both involve modification and/or transformation of the firm's organizational culture. According to Bowen and Lawler (1992), they promote technical proficiency and some degree of employee involvement as an integral part of an organizational change endeavor (Manz and Stewart, 1997).

Quality is a multidimensional concept and QM is a holistic philosophy of management, including different principles linked to different aspects of quality. Therefore, the application of the STS in the field of quality maintains the coexistence of intertwined social and technical subsystems in the QM reflected by a number of quality practices required by the various international quality models and standards (Shah and Ward, 2007; Wang et al., 2010; Zeng et al., 2017; Zu, 2009). For instance, Spencer (1994) has explained that TQM is a management system that captures characteristics of the different mechanistic, organic and cultural organizational models and operationalize them by proposing methodologies for use (Table I). Like TQM, the ISO 9001 QMs can be constituted following the same logic by incorporating some characteristics of these organizational models, since the ISO 9001 and TQM share common dimensions (Martínez-Costa et al., 2009) and there is empirical evidence that demonstrates the strong link between ISO 9001 and TQM (Terziovski and Guerrero, 2014). The ISO 9000 standards can be a stepping-stone to the implementation

\begin{tabular}{llll}
\hline & Mechanistic model & Organic/systems model & TQM \\
\hline Organizational & $\begin{array}{l}\text { Create profits for the } \\
\text { purposes }\end{array}$ & System goals (namely the & The ultimate goal is to better
\end{tabular}

purposes shareholders; focus on productivity and efficiency need to survive) surpass individual performance goals by improving the quality of products and processes; TQM views profitability as an outcome of satisfying customers; the TQM organization works to satisfy all its stakeholders

Quality Conformance to internally definition derived standards $\begin{array}{ll}\text { Management } & \text { Plan, organize, direct } \\ \text { role } & \text { and control }\end{array}$

Employees' role

Follow orders and carry out specialized tasks within specified positions

Organizational Vertical hierarchy, whose structure major objectives are accountability and control; division of labor and functional areas

Values

Stability
Table I.

\section{TQM and} organizational models
Quality essentially means adaptability to the changing environment

Conformance to standards derived from customer needs, which evolve over time; stakeholders delight

Act as a brain of the system, Lead, partner, and assess; creating a vision for the organization

Contribute to the overall organizational purpose

Shared beliefs replace the hierarchical command system as a means of control; processes; boundaries coordination and information sharing

Adaptability, complexity, and learning create a vision that regards TQM as an integral part of the business; walk the talk Self-management and participative decision-making framed by the organizational values and purpose, which are shared and accepted by all Flat; horizontal design based on the flow of work

between functions are eliminated to facilitate coordination.

Cooperation and partnership; continuous improvement and learning; innovation

Sources: Adapted from Spencer (1994); Abrunhosa and Moura E Sá (2008, p. 210) 
of TQM (Antony et al., 2002; Quazi and Padibjo, 1997), or even more, it complements TQM (Anderson et al., 2009; Gotzamani and Tsiotras, 2002; Magd and Curry, 2003). Furthermore, Jayaram et al. (2010) argue that the design of quality management systems collectively encompasses a sociotechnical mix of practices. Indeed, many authors have adopted this dichotomy of social and technical systems to study the practices of quality management in relation to performance (Abdullah et al., 2009; Cho et al., 2017; Flynn et al., 1995; Rahman and Bullock, 2005). Others have utilized it in innovation-related issues (Abrunhosa and Moura E Sá, 2008; Feng et al., 2006; Fotopoulos and Psomas, 2009; Lakhal et al., 2006; Prajogo and Sohal, 2004; Zeng et al., 2015).

The social QMs (ISO 9001) practices reflect the paradigm of soft managerial change, which embraces reflection engagement, empowerment and intelligence gathering and knowledge diffusion/sharing (Bourke and Roper, 2017). They consist of social, culture, learning and relationship-driven practices of the QMs (Flynn et al., 1995; Rahman and Bullock, 2005; Sitkin and Sutcliffe, 1994; Wilkinson, 1992). These practices are broadly captured at the strategic or organizational level by embodying strategic planning (Samson and Terziovski, 1999), open organization (Powell, 1995), visionary leadership and shared vision (Anderson et al., 1995; Dow et al., 2009) and employee relations (Saraph et al., 1989). At the inter-organizational level, it includes customer and suppliers relationships (Flynn et al., 1995).

The technical practices of QMs (ISO 9001) are related to the paradigm of hard managerial changes typically emphasize rules, formality, conformity, discipline, stability and standardization (Bourke and Roper, 2017). The technical practices are more technologydriven and control-oriented, focusing on a cybernetic control system to reduce defects and variation in processes and products to fulfill quality standards and meet manufacturing established requirements and specifications (Dow et al., 2009; Flynn et al., 1995; Naor et al., 2008; Powell, 1995; Prajogo and Sohal, 2004; Sitkin and Sutcliffe, 1994). They involve the use of scientific methods and statistical tools (Abdallah, 2013; Flynn et al., 1995; Sousa and Voss, 2002).

Social and technical QM practices are extensively studied according to TQM. Excepting Bakotić and Rogošić (2015) who studied the impact of social QMs (ISO 9001) practices on the implementation of the technical practices, practically no research has adopted this taxonomy for QMs (ISO 9001). This study follows Bakotić and Rogošić (2015) and considers the QMs (ISO 9001) practices of leadership, customer focus, involvement of people and mutually beneficial supplier relations as social practices, whereas the technical practices embrace continual improvement, process approach, system approach to management and factual approach to decision making (Table II).

\subsection{Product innovation}

A simpler way to distinguish innovations is to perceive them according to their area of application. In this case, innovation can be product innovation, process innovation, marketing innovation or organizational innovation (Damanpour, 1991; OECD, 2005). Otherwise, in a highly competitive changing environment, introducing product innovation is an imperative strategy to face the aggressive competition and sustain a solid competitive advantage.

Product innovation is a new product or service developed to satisfy external customers or market need. According to the Oslo manual "A product innovation is the introduction of a good or service that is new or significantly improved with respect to its characteristics or intended uses. This includes significant improvements in technical specifications, components and materials, incorporated software, user friendliness or other functional characteristics" (OECD, 2005, p. 4). Therefore, product innovation can be associated with either the amelioration of existing products or the creation new market. The former reflects incremental product innovation which consists of pursuing an exploitation-based innovation strategy to primarily seek out opportunities located in firm's surrounding environment by extending existing products and services to existing customers, building on 


\begin{tabular}{|c|c|c|}
\hline & Practices & Description \\
\hline \multirow[t]{4}{*}{$\begin{array}{l}\text { Social } \\
\text { practices }\end{array}$} & Leadership & $\begin{array}{l}\text { Leaders establish unity of purpose and direction of the } \\
\text { organization. They should create and maintain the internal } \\
\text { environment in which people can become fully involved in } \\
\text { achieving the organization's objectives }\end{array}$ \\
\hline & Customer focus & $\begin{array}{l}\text { Organizations depend on their customers and therefore should } \\
\text { understand current and future customer needs should meet } \\
\text { customer requirements and strive to exceed customer expectations }\end{array}$ \\
\hline & Involvement of people & $\begin{array}{l}\text { People at all levels are the essence of an organization, and their } \\
\text { full involvement enables their abilities to be used for the } \\
\text { organization's benefit }\end{array}$ \\
\hline & $\begin{array}{l}\text { Mutually beneficial } \\
\text { supplier relationships }\end{array}$ & $\begin{array}{l}\text { An organization and its suppliers are interdependent and mutually } \\
\text { beneficial }\end{array}$ \\
\hline \multirow[t]{4}{*}{$\begin{array}{l}\text { Technical } \\
\text { practices }\end{array}$} & Continuous improvement & $\begin{array}{l}\text { Continuous improvement of the organization's overall performance } \\
\text { should be a permanent objective of the organization }\end{array}$ \\
\hline & Process approach & $\begin{array}{l}\text { The desired result is achieved more efficiently when activities and } \\
\text { related resources are managed as a process }\end{array}$ \\
\hline & $\begin{array}{l}\text { System approach to } \\
\text { management }\end{array}$ & $\begin{array}{l}\text { Identifying, understanding, and managing interrelated processes as } \\
\text { a system contributes to the organization's effectiveness and } \\
\text { efficiency in achieving its objective }\end{array}$ \\
\hline & $\begin{array}{l}\text { Factual approach to } \\
\text { decision making }\end{array}$ & Effective decisions are based on the analysis of data and information \\
\hline
\end{tabular}

Source: Dale (2015)

Table II.

The ISO 9001 standard's social and technical practices

existing knowledge skills and capabilities (March, 1991). The later involves radical product innovation which breaks with existing and dominant learning logic (Enkel and Gassmann, 2010) through activities such as research, variation, risk-taking, experimentation and discovery (March, 1991). Firms that engage in this exploration-based innovation strategy go beyond internal research (Enkel et al., 2017) and experiment with new ideas and ways of doing things that generate new knowledge and skills (Newman et al., 2016).

In this study, we define incremental product innovation as the introduction of a significantly improved product and radical product innovation in terms of products that are new for both of the firm and the industry.

\subsection{The sociotechnical ISO (9001) quality management system and product innovation} 2.3.1 The impact of the social QMs (ISO 9001) practices on product innovation. Several studies confirm that the social practices of QM positively impact new or significantly improved products (Feng et al., 2006; Prajogo and Sohal, 2004; Song and Su, 2015; Zeng et al., 2017). More specifically, the study by Abrunhosa and Moura E Sá (2008) proved that social practices have a positive association with the adoption of incremental product innovation. Another more recent study in the context of service firms conducted by Khan and Naeem (2018) concluded that social practices have a significant impact on both incremental and radical service innovation. Indeed, it appears that the social aspect of QM supports incremental and radical product innovation. This can be explained by the fact that these practices (e.g. leadership, customer focus, people involvement, mutually beneficial supplier relations) can create a fertile platform or environment for the development of different types of product innovation (Prajogo and Sohal, 2006a, b; Song and Su, 2015).

Leadership is a key element of quality performance (Ravichandran and Rai, 2000), it not only drives the firm's quality strategy but also considerably guides innovation in the organization (Tang, 1998). Firms that are strongly committed to producing high-quality products are also very active in introducing product innovation (Lin and Lu, 2006; 
Prajogo and Sohal, 2003). In that sense, top management's commitment to Quality can also help to engage in innovation by providing and allocating the necessary human and material resources. The leadership role is to encourage and inspire the entire organization through the behavior and attitudes of the top management to participate in decision making and to propose innovative ideas to solve problems and improve products (Sadikoglu and Zehir, 2010). This implies creating and maintaining an organizational climate with a vision and values that cultivate and recognize innovation at all organization's levels (Ahmed, 1998). According to Manders et al. (2016), leadership should stimulate the generation of ideas in the organization and thus support incremental and radical product innovation.

An appropriate HRM strategy is generally associated with the successful integration of innovations in the workplace (Baldwin and Johnson, 1996). The firm's employees play an important role in innovation through their ability to find new ideas and create knowledge (McAdam, 2004; Molina et al., 2007). The QM is very useful in this regard because it is based on the belief that the employee empowerment, training, and teamwork lead to employee satisfaction and motivate them to continually generate novel ideas that facilitate rapid development of incremental and radical product innovations (Abrunhosa and Moura E Sá, 2008; Prajogo and Sohal, 2004; Sadikoglu and Zehir, 2010; Zeng et al., 2017). Empowerment offers employees more independence and encourages creative thinking about how work is organized (Tarí et al., 2007). Teamwork allows employees to absorb knowledge from design and manufacturing practices and routines, and create new practices necessary for new product development (Song and Su, 2015). Training also enables employees to become more receptive to innovations as they see their skills develop by using new techniques and tools needed to identify and solve problems related to product innovation (Kim et al., 2012; Lee et al., 2010; Song and Su, 2015). All these practices lead to knowledge and experience exchange between employees and therefore provide them with enough knowledge to implement innovation (Perdomo-Ortiz et al., 2006).

The QMs (ISO 9001) assists the organization to focus on its customers and regularly seek out their new needs and expectations (Prajogo and Sohal, 2001). According to Benner and Tushman (2003), focusing on market or customer trends is a useful practice to solve the dilemma of exploitative and exploratory innovation. Because the development of incremental or radical product innovations depends heavily on the firm's openness on its customers (Arnold et al., 2011; Chang and Taylor, 2016; Lau et al., 2010; Menguc et al., 2014). In fact, QM practice of customer focus can foster firms learning (Dean and Susman, 1989), through the absorption of new product ideas directly from market or customer, and consequently, it can continuously adapt to their changing needs by developing and introducing new products beyond the simple compliance to standards (Prajogo and Sohal, 2001, 2003).

On the other hand, high-performing suppliers are also recognized to have an important role in incremental and radical product innovation (Lau et al., 2010; Menguc et al., 2014; Song and Thieme, 2009). For QMs (ISO 9001), firms should select and work with the best suppliers and establish a mutually beneficial relationship with them. Bozdogan et al. (1998) note that through mutually beneficial commitments with suppliers, firms can gain innovation through proactively developing new products with their suppliers. Indeed, suppliers can share knowledge, ideas and know-how that the firm needs for its incremental or radical product innovation projects, which is likely to enrich its knowledge base and subsequently improve its ability to be more innovative (Kim et al., 2012; Petersen et al., 2005).

In light of this theoretical discussion, we hypothesize that the social practices of QMs (ISO 9001) encourages incremental and radical product innovation. On the one hand, leadership practices and employee involvement help the firm to establish an internal 
organization encouraging incremental and radical product innovation. On the other hand, customer focus and mutually beneficial supplier relations can make the firm more innovative by adopting an open innovation behavior toward its stakeholders:

H1a. The social QMs (9001) practices have a positive and significant impact on incremental product innovation.

H1b. The social QMs (9001) practices have a positive and significant impact on radical product innovation.

2.3.2 The impact of the technical QMs (ISO 9001) practices on product innovation. In light of previous research, there is a weak and even negative relationship between $\mathrm{QM}$ and product innovation when considering the technical QM practices (Prajogo and Sohal, 2001, 2003). More specifically, referring to Abrunhosa and Moura E Sá (2008), López-Mielgo et al. (2009) and Prajogo and Sohal (2004), the technical QM practices seem to hinder product innovation but only when it is radical. Even though the technical practices of QMs (ISO 9001) or TQM, can hinder innovation (Naveh and Erez, 2004; Singh and Smith, 2004; Wei, 2010; Wind and Mahajan, 1997), the negative results of the literature do not totally reject the positive view of the effect of QM but show that it will support innovation only on a very limited basis and in some measures (Castillo-Rojas et al., 2012; Prajogo and Sohal, 2001).

The QMs (ISO 9001) positively influences the launch of new incremental products because the ISO 9001 standard requires adhering to the philosophy of continuous improvement (PDCA) (Prester and Bozac, 2012). Continuous improvement focuses on analytical, structural and linear thinking based on the use of firm's previous knowledge and capabilities, which are obsolete to create entirely new products considering that radical innovation requires synthetic, unstructured, and nonlinear thinking (Benner and Tushman, 2002; Prajogo and Sohal, 2001; Tushman and Anderson, 1986). Continuous improvement also creates an organizational climate that focuses on incremental changes, and encourage employees to risk aversion and failure avoidance, which is in contradiction with the radical innovation spirit characterized by a high level of risk and uncertainty (O'Connor and Rice, 2013; Santos-Vijande and Álvarez-González, 2007). This joins Blank and Naveh (2014) who empirically proved that the climate installed by QM within the organization is negatively associated with the performance of radical product innovation.

In the same line of thought, and as it was shown by (Benner and Tushman, 2002; Madanmohan, 2005), the process approach also generates incremental product innovation, because it is associated with high levels of formalization, standardization and control (Prajogo and Sohal, 2004) that increase bureaucracy and rigidity (Dick, 2000; Jayawarna and Pearson, 2001; Slater and Narver, 1998). Song and Su (2015) explain that the creation of new products involves extremely high levels of innovativeness and strict control will largely harm creativity. A strong focus on compliance and the reduction of errors and changes in processes will lock employees, notably R\&D managers, in an adaptive learning mode (Argyris and Schön, 1978). Consequently, that can be a source of demotivation and loss of enthusiasm since they are not willing to be freely creative and to think of radical changes (Song and Su, 2015).

Product innovation requires close cooperation between the organizational processes. This cooperation can be improved by the systemic approach of QMs (ISO 9001) (Pekovic and Galia, 2009). However, linking processes during a product innovation project may change the focus of a radical product project toward focusing on improving current customer needs (Cole and Matsumiya, 2007). Also, that can increase the power or pressure exercised by some departments that have a risk aversion behavior and focus more on incremental innovations (Manders et al., 2016). In some cases, this can lead to intra-organizational conflicts and the disintegration of some managers during a product 
innovation project, especially for radical product innovation, which necessitates effective collaboration between the different departments.

Firms adopting QMs (9001) collect quality data and then act on the results obtained from the analysis of this data (Benner and Tushman, 2002). Decision-making based on timely and reliable quality data and information contributes to the rapid introduction of innovative products into the market (Flynn, 1994; Sadikoglu and Zehir, 2010). Managing information using the factual approach to decision making is the most important of QMs (ISO 9001) technical practice that can be applied to innovation activities (Miller, 1995). However, this approach favors more incremental product innovation that tends to emerge from factual information because the radical product innovation begins with intuitive, risky and difficult-to-measure ideas that will eventually be subjected to a factual verification (Miller, 1995; Sethi and Sethi, 2009).

The technical or control-oriented model of the QM focuses more on quality through compliance (Prajogo and Sohal, 2004). According to Feng et al. (2006) and Prajogo and Sohal (2003), the technical QM practices are significantly related to product quality performance. In this technical model, stability and reduction of variations are appreciated as they increase predictability, which, in turn, increases control (Song and Su, 2015; Spencer, 1994). Hence, the current technical capabilities provided by QMs (ISO 9001) through the practices of continual improvement, process approach, system approach to management and factual approach to decision making, used for product quality improvement are more susceptible to build incremental product innovation. Prester and Bozac (2012) have shown that ISO 9001 contributes negatively to revenues from radically new products, probably due to the additional documentation needed to approve this new product:

H2a. The technical QMs (9001) practices have a positive and significant impact on incremental product innovation.

H2b. The technical QMs (9001) practices have a negative and significant impact on radical product innovation.

2.3.3 The impact of the social and technical QMs (ISO 9001) practices on product innovation. QM practices have been discussed as being conceptually interrelated building up a management system (Anderson and Gerbing, 1988; Calvo-Mora et al., 2013; Flynn et al., 1994). The effectiveness of an organization's quality management system is determined by all its different practices $(\mathrm{Zu}, 2009)$. The main QM practices are usually implemented in combination, and it is their interaction and joint variance that assure creating a superior quality performance (Dow et al., 2009). The existing empirical literature recognizes the strong retroactive interaction between the social and technical practices of QM. From one side, it has been largely documented that the social practices represent the infrastructure of the successful implementation of the technical practices in regard to the development of performance (Anderson et al., 1995; Flynn et al., 1995; Ho et al., 2001; Kaynak, 2003; Lakhal et al., 2006; Patyal and Koilakuntla, 2017; Rahman and Bullock, 2005; Wu et al., 2015; Zu, 2009) or the development of innovation (Flynn et al., 1995; Khan and Naeem, 2018; Kim et al., 2012; Zeng et al., 2015, 2017). Particularly, for the QMs (ISO 9001), Bakotić and Rogošić (2015) found that social QMs (ISO 9001) practices are a key determinant of the technical practices. From the other side, and inversely, Cho et al. (2017) showed that social QM practices positively mediate the relationship between technical practices and firm performance.

From the perspective of the STS, the maximization of the organizational innovation capacity will depend on the tight interdependencies between QMs social and technical subsystems and their joint co-optimization (Hendrick, 1997; Koukoulaki, 2014). This advocates the necessity of taking into account both of the social and technical subsystems when the firm anticipate introducing change within the organization through innovation 
(Cherns, 1987; Power and Singh, 2007). For instance, when studying the role of the multidimensionality of TQM practices in determining quality and innovation performance, the findings of Prajogo and Sohal (2004) supports the coexistence of the social and technical TQM practices within the organization in a holistic manner even if these practices are contradictory in nature. Perdomo-Ortiz et al. (2006) assert that both social and technical dimensions of TQM play a significant role in building innovation capability. Previously, Bourke and Roper (2017) showed that the positive complementarities between contrasting soft and hard QM dimensions might benefitting product innovation performance.

The ISO 9001 standard is based on well-defined practices that specified the basic requirements for a quality management system. In order for QMs to succeed, these practices should all be implemented respectively given that QM is an integrated approach (Bakotić and Rogošić, 2015). Moreover, to be able to stimulate product innovation, QMs (ISO 9001) needs to be taken as part of a broader organizational change strategy and not as a set of isolated social and technical practices (Kochan et al., 1995). Therefore, we consider that QMs (ISO 9001) is an integral and complex system of management containing interdependent social and technical subsystems that should be put into practice. Those subsystems will have a synergistic effect on incremental and radical product innovation, their complementarity helps to overwhelm the limits of one by the advantages of the other. For example, the technical practices disadvantages for radical product innovation might be reduced through the social practices. Yet, studies showed that technical practices need social ones to a better implementation for innovation; on the other side, the impact of social practices on innovation goes through technical practices (Khan and Naeem, 2018; Zeng et al., 2017; Zeng et al., 2015). Perdomo-Ortiz et al. (2006) confirmed that both the social and technical dimensions of QM play an important role in building the company's innovation capabilities. Indeed, as a sociotechnical system, considering or designing a change to just one of two subsystems of QMs (ISO 9001) and neglecting the other will limit the effectiveness of the product innovation development:

H3a. The sociotechnical QMs (ISO 9001) has a positive and significant impact on incremental product innovation.

H3b. The sociotechnical QMs (ISO 9001) has a positive and significant impact on radical product innovation.

\section{Research methodology}

\subsection{Sample and data collection}

As all the measurement scales were adopted from previous Anglo-Saxon literature, we opted the double-back translation method to translate them into French. This method is widely used in the social sciences to test the accuracy of the translation and to detect its errors (Brislin, 1970; Craig and Douglas, 2000; Douglas and Craig, 2007). Once the French version of the measurements scales was done, we prepared a first version of the questionnaire that was revised by 11 individuals: two professors in quality and marketing management, three doctoral students in economics and management, two experts in innovation surveys and market research and four quality managers. The objective was to ensure clarity of content and the understanding of questions and items, to review the length of the questionnaire, its structure, and layout. The suggestions and modifications gathered were very helpful in improving and developing the second version of the questionnaire. Then, a questionnaire pretest for this second version was conducted with 20 firms to evaluate the reliability and validity of the measurement scales within the Moroccan context.

This study concerns innovative and ISO 9001 certified Moroccan firms. Since it was difficult to estimate this population of firms, we chose a non-probabilistic method, namely, 
the judgment sampling, to build a sample that meets the two predetermined criteria by merging the databases of the Moroccan Association of R\&D and the Moroccan Association of Quality and Management. From January to May 2017, we sent an e-mail with a cover letter explaining the purpose of the research and mentioning a link to the online selfadministered survey to 323 e-mail addresses randomly extracted from the merged databases. These databases include manufacturing and service firms. The questionnaire was addressed in the first place to quality managers as they are the key persons to have an important role in quality strategy and a deep understanding of the QMs (ISO 9001) of the organization. Thus, they are more qualified to understand the questions and provide relevant information about the QMs practices.

In total, we received 82 exploitable responses after rejecting 30 questionnaires with missing data and from firms that did not introduce any product innovation in the last five years. This represents a response rate of 25 percent judged tolerable in comparison with the response rates in the management studies ranging between 10 and 32 percent (Yusr et al., 2017). Additionally, the number of returned responses assures the minimum sample size required to use PLS equation-modeling method (PLS-SEM). It respects the "rule of ten" stipulating that the minimum sample size should be 10 times the largest number of the regression paths pointing a construct in the inner model, or 10 times the largest number of indicators for the most complex formative construct, or 10 times the largest number of any dependent construct (Barclay et al., 1995). In our case, for example, the formative constructs of social or technical QMs (ISO 9001) practices have the largest complex multiple regression in the model with 4 regression paths each. Accordingly, we need a sample size of $4 \times 10=40$. Also, the dependent variables of incremental/radical product innovation have a large number of eight indicators, so we will need $8 \times 10=80$ observations. In both cases, with 82 responses, our sample appears to be sufficient to allow PLS analysis to have a satisfactory statistical power. The demographics of the sample and the profile of respondents are shown in Table III.

\subsection{Variables measurement}

3.2.1 Independent variables. As previously discussed, the construct of QMs (ISO 9001) social practices has four dimensions of practices: leadership, customer focus, people involvement and mutually beneficial supplier relationships. Based on scales developed by Lee et al. (2009),

\begin{tabular}{|c|c|c|c|c|c|}
\hline Firm Characteristics & Frequency & $\%$ & Respondent characteristics & Frequency & $\%$ \\
\hline Industry types & & & Gender & & \\
\hline Industry & 65 & 79.3 & Female & 29 & 35.4 \\
\hline Service & 17 & 20.7 & Male & 53 & 64.4 \\
\hline \multicolumn{3}{|c|}{ Annual revenue (in millions of dirhams ${ }^{a}$ ) } & Age & & \\
\hline$<1$ & 10 & 12.2 & $20-30$ & 37 & 45.1 \\
\hline $1-10$ & 16 & 19.5 & $31-40$ & 25 & 30.5 \\
\hline $10-175$ & 29 & 35.4 & $41-50$ & 14 & 17.5 \\
\hline$>175$ & 27 & 32.9 & $>50$ & 6 & 7.3 \\
\hline \multicolumn{3}{|l|}{ No. of employees } & Position & & \\
\hline$<10$ & 5 & 6.1 & Owner & 11 & 13.4 \\
\hline $10-49$ & 11 & 13.4 & Quality manager & 62 & 75.6 \\
\hline $50-249$ & 29 & 35.4 & R\&D manager & 4 & 4.9 \\
\hline $250-500$ & 33 & 4.9 & Other & 5 & 6.1 \\
\hline$>500$ & 4 & 4.9 & & & \\
\hline
\end{tabular}

Notes: ${ }^{\text {a }}$ The Moroccan Dirham (MAD) is the official currency of Morocco (1\$=9.36559 MAD); August 28, 2017 
we use five items to measure leadership, customer focus and people involvement, and four items for mutually beneficial supplier relations. Similarly, the QMs (ISO 9001) technical practices construct is composed of four dimensions: continuous improvement; process approach; system approach to management; factual approach to decision making. To measure these variables, we adopted five items for continual improvement from (Psomas and Antony, 2015), and four items for process approach, three items for system approach to management and three items Factual approach to decision making from Lee et al. (2009).

3.2.2 Dependent variables. To establish the measurement scales for this two dependent variable, eight items for each of incremental and radical product innovation were adopted from the studies of Guimarães et al. (2016), Kim et al. (2012) and Prajogo and Sohal (2006b).

All the measurement scales were a seven-point Likert scale ranging from (1) "I totally disagree" to (7) "I totally agree."

\section{Analysis and results}

The conceptual model exposed in Figure 1 has been tested using the partial least squares (PLS) technique through the SmartPLS 3 software (Ringle et al., 2005). We opted for this variance-based SEM method for the following reasons: our study is concerned with the prediction of the endogenous variables (Chin, 2010). The PLS algorithm does not require data to be normally distributed (Hair et al., 2014). PLS has good statistical power and it is more efficient in the case of very small samples like in our study $(n=82)$ and as noted by Reinartz et al. (2009), PLS must be applied when the research sample is lower than 250 observations. SmartPLS is also more appropriate for studies that incorporate second-order constructs in their research models.

About this latter reason, our conceptual model contains two second-order constructs and one third-order construct. Therefore, by considering all of our constructs as reflective, we started by specifying Model (1) (Figure 1) which takes into consideration the two dependent variables (incremental and radical product innovation) and the two reflective-formative second-order constructs of social and technical QMs (ISO 9001) practices. The social practices construct has four reflective first-order dimensions: leadership, customer focus, people involvement, mutually beneficial supplier relations, also the technical practices

Figure 1.

Research conceptual model

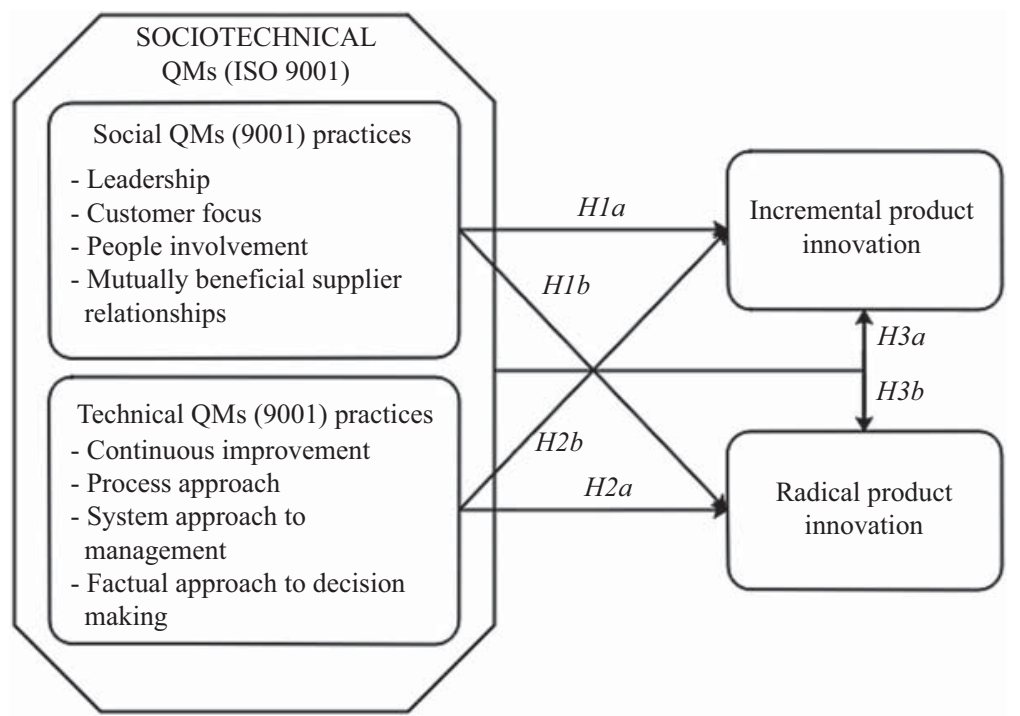


construct includes four reflective first-order dimensions: continual improvement, process approach, system approach to management, factual approach to decision making. To model these two-second order constructs, we use the repeated indicator approach which consists of repeating all the indicators of all the first order construct in the related second-order construct (Becker et al., 2012). The same approach was used to create the third-order construct of Sociotechnical QMs (ISO 9001) with social and technical practices as dimensions (Figure 3).

The procedure of data analysis consists of two main phases: the assessment of the reliability and validity of the measurement model (outer model), and the estimation of the structural model (inner model) to test the research hypotheses. This systematic procedure allows making sure that all constructs' measures have a great level of validity and reliability before moving to test the hypothetical relationships (Roldán and Sánchez-Franco, 2012).

\subsection{Assessment of the measurement model}

Based on authors estimation guidelines (Hair et al., 2011, 2012, 2014; Henseler et al., 2009), the assessment of the different reflective construct measurement has made in terms of composite reliability, convergent validity and discriminate validity. To be considered satisfactory, composite reliability for each construct should take a value equal to or above 0.70 , we supplemented it by Cronbach's $\alpha$ with the same rule. To assess the convergent validity, all the indicators loadings must be statistically significant and surpass 0.7 , and the average variance extracted (AVE) of each construct have to be about 0.50 or higher (Hair et al., 2014; Henseler et al., 2009). The discriminate validity is evaluated by the means of the Fornell and Larcker (1981) criterion in which the AVE of each construct should be higher than the highest squared correlation with any other construct. In addition, the crossloadings method is used to verify the discriminant validity. In fact, the loadings of each indicator on its construct have to be higher than the cross-loadings on other constructs.

Since both the second- and third-order constructs are formative, the assessment of formative measurement models' guidelines is applied. Thus, we examine the multicollinearity between the lower-order constructs (VIF $<5$, Hair et al., 2017) and the significance of their weights.

The estimation results in Table IV verify that the measurement model meets all common requirements. First, in terms of the internal consistency, the composite reliability and Cronbach's $\alpha$ for each construct are acceptable because it is greater than 0.7 (Table IV). Second, the AVE scores are above the level of 0.5, and, except for one deleted

\begin{tabular}{|c|c|c|c|c|c|c|}
\hline Constructs & & $\begin{array}{l}\text { No. of } \\
\text { items }\end{array}$ & Factor loadings & $\begin{array}{l}\text { Composite } \\
\text { reliability }\end{array}$ & $\begin{array}{c}\text { Cronbach's } \\
\alpha \alpha\end{array}$ & AVE \\
\hline \multirow{4}{*}{$\begin{array}{l}\text { Social } \\
\text { practices }\end{array}$} & Leadership & 5 & $0.797-0.863^{* * *}$ & 0.916 & 0.885 & 0.686 \\
\hline & Customer focus & 4 & $0.702-0.879 * * *$ & 0.876 & 0.811 & 0.641 \\
\hline & People involvement & 5 & $0.834-0.903^{* * *}$ & 0.937 & 0.915 & 0.747 \\
\hline & Mutually beneficial supplier relations & 3 & $0.727-0.859 * * *$ & 0.874 & 0.807 & 0.635 \\
\hline \multirow{4}{*}{$\begin{array}{l}\text { Technical } \\
\text { practices }\end{array}$} & Continuous improvement & 5 & $0.831-0.910^{* * * *}$ & 0.941 & 0.922 & 0.763 \\
\hline & Process approach & 4 & $0.9046-0.954^{* * * *}$ & 0.958 & 0.942 & 0.852 \\
\hline & System approach to management & 3 & $0.883-0.911^{* * *}$ & 0.922 & 0.874 & 0.798 \\
\hline & Factual approach to decision making & 3 & $0.854-0.896^{* * * *}$ & 0.903 & 0.838 & 0.756 \\
\hline Product & Incremental product innovation & 8 & $0.728-0.910^{* * * *}$ & 0.958 & 0.949 & 0.739 \\
\hline Innovation & Radical product Innovation & 8 & $0.901-0.942^{* * *}$ & 0.975 & 0.971 & 0.852 \\
\hline
\end{tabular}

Note: ***Significant at $p<0.05$ 
indicator (CF4), from the variable customer focus, with an item loading of 0.620 , all standardized item loadings of the other indicators exceed 0.7 and were significant at $p<0.01$ (Table IV). Thus, all constructs achieve convergent validity. Finally, all the constructs attain the discriminant validity. The Fornell and Larcker's (1981) criterion is respected, as the square of the AVE for each construct is higher than its squared correlations with all other constructs (Table V). As well, the examination of the crossloadings of the indicators by moving across the rows and going down columns shows that each indicator loads higher on its associated construct than all of its loadings on other constructs (Table VII). It is worth noting that there are some items landings that seem to be quite close to other cross-loadings. Although, and according to (Chin, 2010), it can be seen through their squares that there is a difference between them in terms of their variances with the related constructs. Providing squared results gives a more intuitive interpretation because it represents the percentage overlap between an item and any construct (Chin, 2010). For example, in our case the item CI1 share 69 percent $(0.831 \times 0.831)$ of the variance with its own construct but it just overlaps most at 51 percent $(0.716 \times 0.716)$ with the construct of the factual approach to decision making. Therefore, Chin (2010) adds that this difference may seem to be reasonable, given that the objective is to have a strong nomological network where constructs at the structural level are closely related.

Table V reports the assessment of the formative second and third-order constructs, it shows that their measurement models respect the required conditions. All VIFs are less than 5 and all weight are significant at $p<0.001$ (Tables VI and VII).

\subsection{Assessment of the structural model}

Once the measurement model is reliable and valid, and comes the phase of the assessment of the proposed structural model. Before, we should begin by analyzing the multicollinearity between the exogenous variables, the variance inflation factor (VIF) values should be below the common cut-off threshold of 5 (Hair et al., 2017). The VIFs for social and technical QMs (ISO 9001) are 2.70 pointing out the absence of multicollinearity issues.

The structural model's quality is made by evaluating the coefficient of determination $\left(R^{2}\right)$, the standardized path coefficients $(\beta)$, the effect size $\left(f^{2}\right)$ and the cross-validated redundancy $\left(Q^{2}\right)$ and the standardized root mean square residual (SRMR) (Hair et al., 2014; Henseler, 2017; Henseler et al., 2009; Ringle et al., 2018). Therefore, we start this second phase by running SmartPLS Algorithm to get the standardized path coefficients $(\beta)$ for

Table V.

Measurement model: discriminant validity of the constructs

\begin{tabular}{lllllllllll}
\hline & 1 & 2 & 3 & 4 & 5 & 6 & 7 & 8 & 9 & 10 \\
\hline 1. Ldp & $0.828^{\mathrm{a}}$ & & & & & & & & & \\
2. CF & 0.652 & $0.800^{\mathrm{a}}$ & & & & & & & & \\
3. PI & 0.607 & 0.568 & $0.865^{\mathrm{a}}$ & & & & & & & \\
4. MBSR & 0.410 & 0.490 & 0.408 & $0.797^{\mathrm{a}}$ & & & & & & \\
5. CI & 0.634 & 0.602 & 0.691 & 0.387 & $0.873^{\mathrm{a}}$ & & & & & \\
6. PA & 0.580 & 0.377 & 0.620 & 0.328 & 0.718 & $0.923^{\mathrm{a}}$ & & & & \\
7. SAM & 0.627 & 0.554 & 0.658 & 0.482 & 0.821 & 0.647 & $0.894^{\mathrm{a}}$ & & & \\
8. FADM & 0.625 & 0.640 & 0.869 & 0.426 & 0.822 & 0.604 & 0.773 & $0.869^{\mathrm{a}}$ & & \\
9. IPI & 0.327 & 0.229 & 0.280 & 0.218 & 0.368 & 0.233 & 0.340 & 0.869 & $0.859^{\mathrm{a}}$ & \\
10. RPI & 0.151 & 0.078 & 0.170 & -0.007 & 0.272 & 0.084 & 0.184 & 0.222 & 0.713 & $0.911^{\mathrm{a}}$
\end{tabular}

Notes: Ldp, leadership; CF, customer focus; PI, people involvement; MBSR, mutually beneficial supplier relations; CI, continual improvement; PA, process approach; SAM, system approach to management; FADM, factual approach to decision making; IPI, incremental product innovation; RPI, radical product innovation; ${ }^{\mathrm{a}} \mathrm{AVE}$ square root values 


\begin{tabular}{|c|c|c|c|c|}
\hline Relationships with first-order dimensions & $\beta$ & $t$-stat. & VIF & \\
\hline \multicolumn{5}{|l|}{ Second-order formative construct } \\
\hline \multicolumn{5}{|l|}{ Social practices } \\
\hline Leadership & 0.377 & $13.058^{* * * *}$ & 2.04 & \\
\hline Customer focus & 0.254 & $10.185^{* * * *}$ & 2.05 & \\
\hline People involvement & 0.398 & $8.557 * * *$ & 1.76 & \\
\hline Mutually beneficial supplier relations & 0.197 & $6.198 * * *$ & 1.73 & \\
\hline \multicolumn{5}{|l|}{ Technical practices } \\
\hline Process approach & 0.286 & $12.306^{* * * *}$ & 2.11 & \\
\hline Continuous improvement & 0.389 & $16.154 * * *$ & 4.89 & \\
\hline System approach to management & 0.223 & $12.141^{* * *}$ & 3.45 & \\
\hline Factual approach to decision making & 0.215 & $13.114^{* * * *}$ & 3.39 & \\
\hline \multicolumn{5}{|l|}{ Third-order formative construct } \\
\hline Sociotechnical QMs (ISO 9001) & & & & \\
\hline Social practices & 0.391 & $2.746^{* * * *}$ & 2.68 & Assessment of the \\
\hline Technical practices & 0.564 & $4.253 * * * *$ & 2.68 & higher-order \\
\hline \multicolumn{4}{|l|}{ Notes: $t$-value is greater than $2.58 * * * p<0.01$} & constructs \\
\hline
\end{tabular}

each cause-effect relationship, the $R^{2}$ coefficients for the dependent variables, and the size effect $\left(f^{2}\right)$. Since the acceptable levels of $R^{2}$ depend on research context (Hair et al., 2012), this study considers the rule of thumb proposed by Cohen (1988) to accept $R^{2}$, values of $0.26,0.130 .02$ are respectively interpreted as substantial, medium, weak levels of predictive accuracy. For the size effect $\left(f^{2}\right)$, values of $0.02,0.15$ and 0.35 represent small, medium and large effects (Cohen, 1988). After that, the bootstrapping technique using 1,000 bootstrap resamples with no sign change (Chin, 1998; Hair et al., 2012) was carried out in SmartPLS to generate the statistical significance ( $t$-values) for each path in the model. Finally, we pursue the blindfolding procedure cross-validated redundancy $\left(Q^{2}\right)$. For a specific endogenous construct, a Stone-Geisser's $Q^{2}$ value superior to zero states that the proposed path model has a satisfactory predictive relevance (Henseler et al., 2009). Finally, the predictive relevance of the models is examined by looking at the SRMR, a value of 0.08 or 0.10 indicates that the model has a good model fit (Henseler et al., 2014; Hu and Bentler, 1999). All these model assessment criteria are summarized in Table VIII.

From the Model (1) (Figure 2) and Table VIII, Bootstrapping results revealed no significant impact of social practices on incremental product innovation $(\beta=0.123$, $t$-value $=0.869)$ and radical product innovation $(\beta=-0.079, t$-value $=0.419)$. Similarly, the technical practices do not have a significant impact on incremental product innovation $(\beta=0.271, t$-value $=1.602)$ and radical product innovation $(\beta=0.283, t$-value $=1.616)$. Therefore, $H 1 a, H 1 b, H 2 a$ and $H 2 b$ were rejected. Although, in terms of $R^{2}$, the model (1) point out that both social and technical practices respectively explained 14 and 5 percent of incremental product innovation and radical product innovation. The SRMR value for the first model was 0.078 , which is less than the value of 0.08 ( $\mathrm{Hu}$ and Bentler, 1999).

The obtained results in Model (2) (Figure 3) and Table VIII indicate that QMs (ISO 9001) has a positive and significant impact on incremental product innovation $(\beta=0.375$; $t$-value $=3.538, p<0.01$ ), in comparison to its weak impact on radical product innovation $(\beta=0.199 ; t$-value $=1.852 ; p<0.010)$. Thus, supporting $H 3 a$ and $H 3 b$. The $R^{2}$ coefficients are 0.141 and 0.040 for incremental product innovation and radical product innovation, respectively. They indicate that the total effect of QMs (ISO 9001) explains 14.1 percent of 


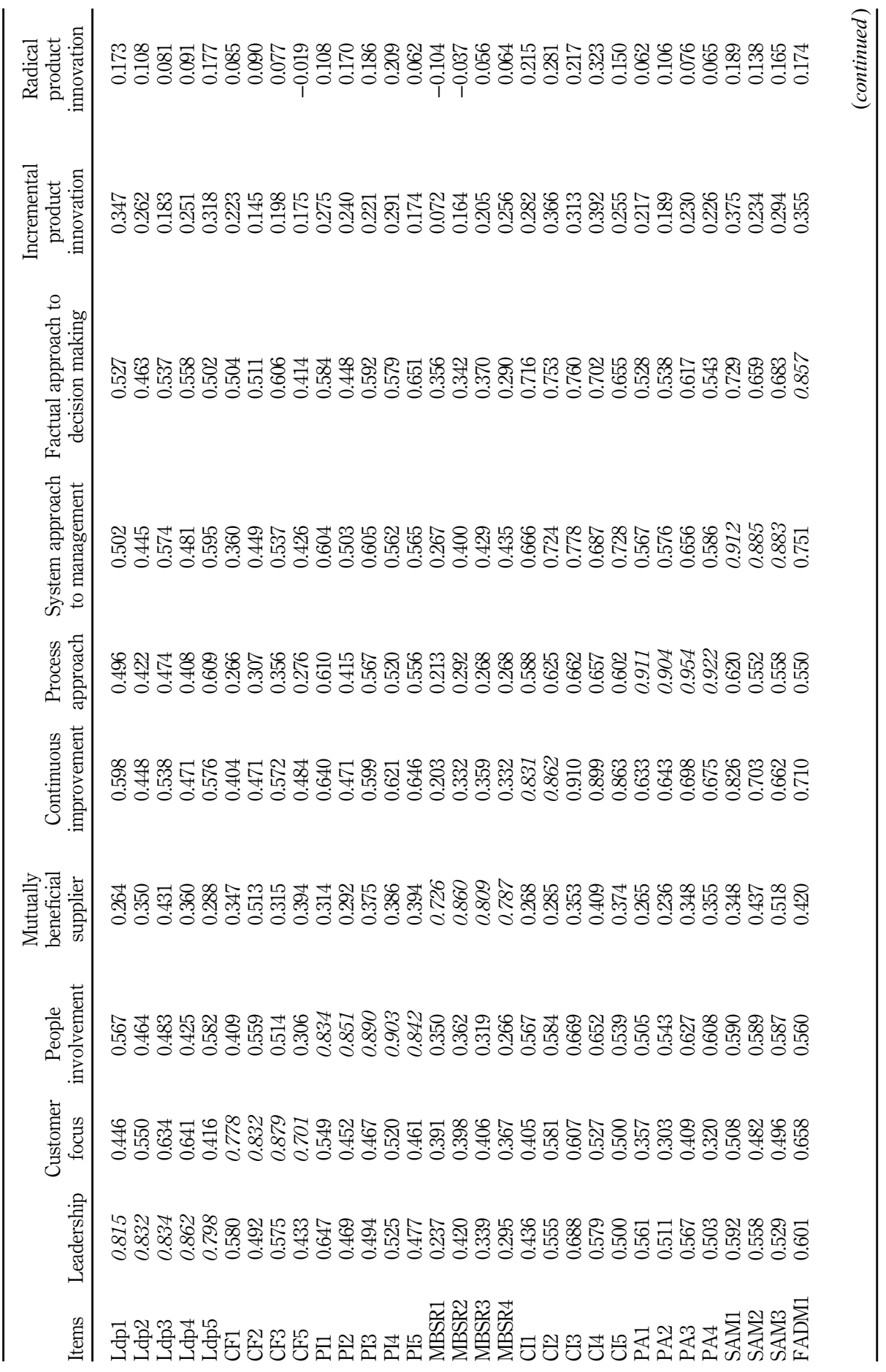

Table VII.

Items cross factor loadings 


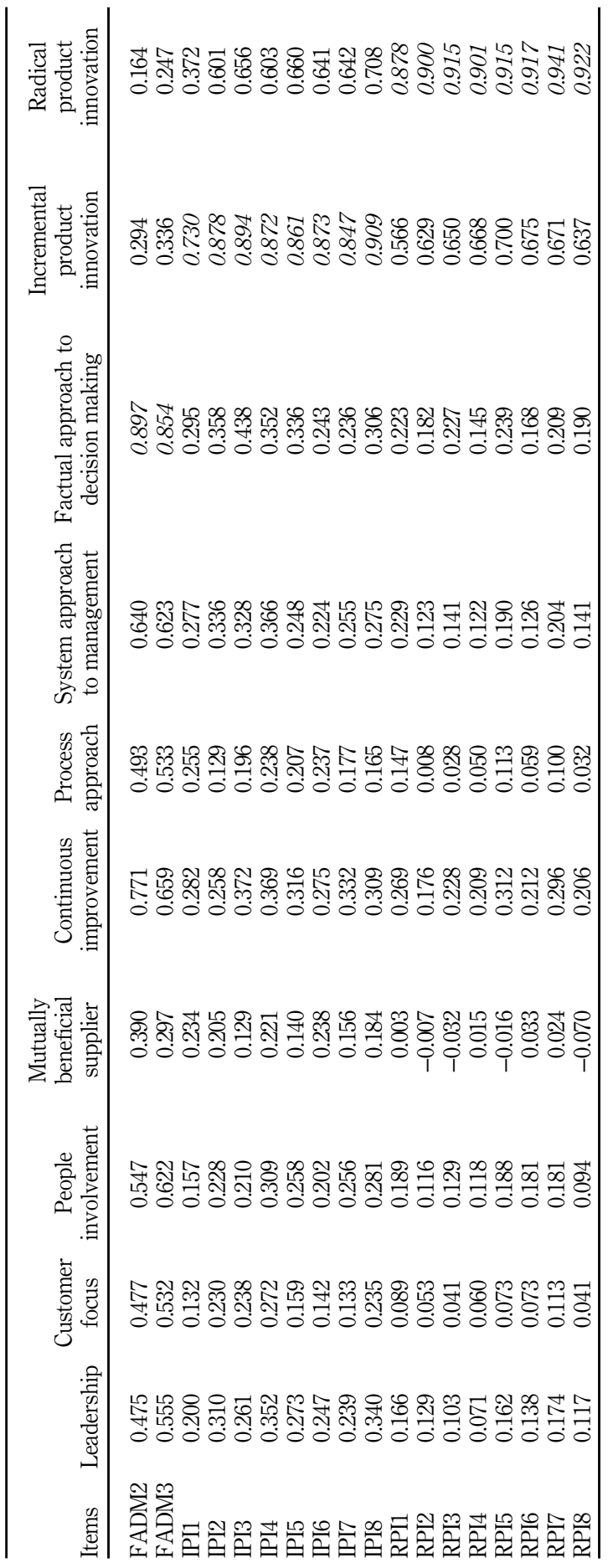

Table VII. 


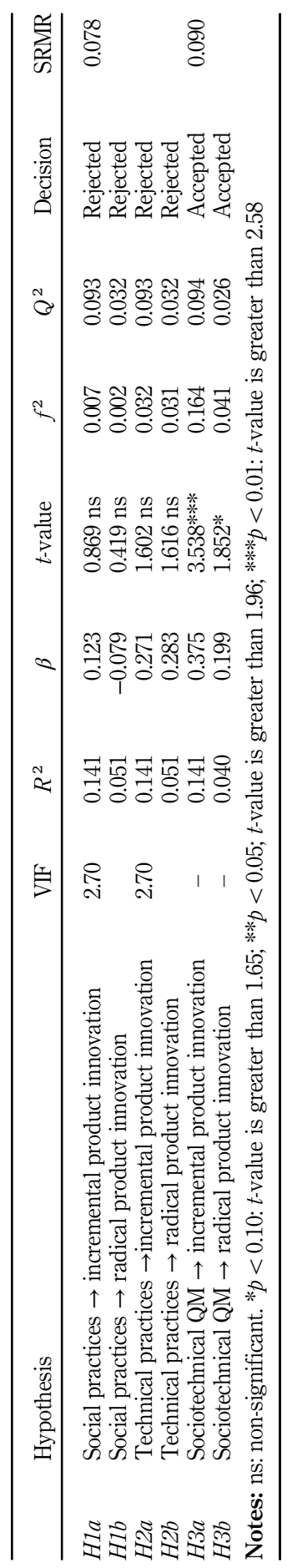

Table VIII.

Hypothesis test

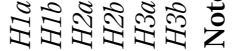




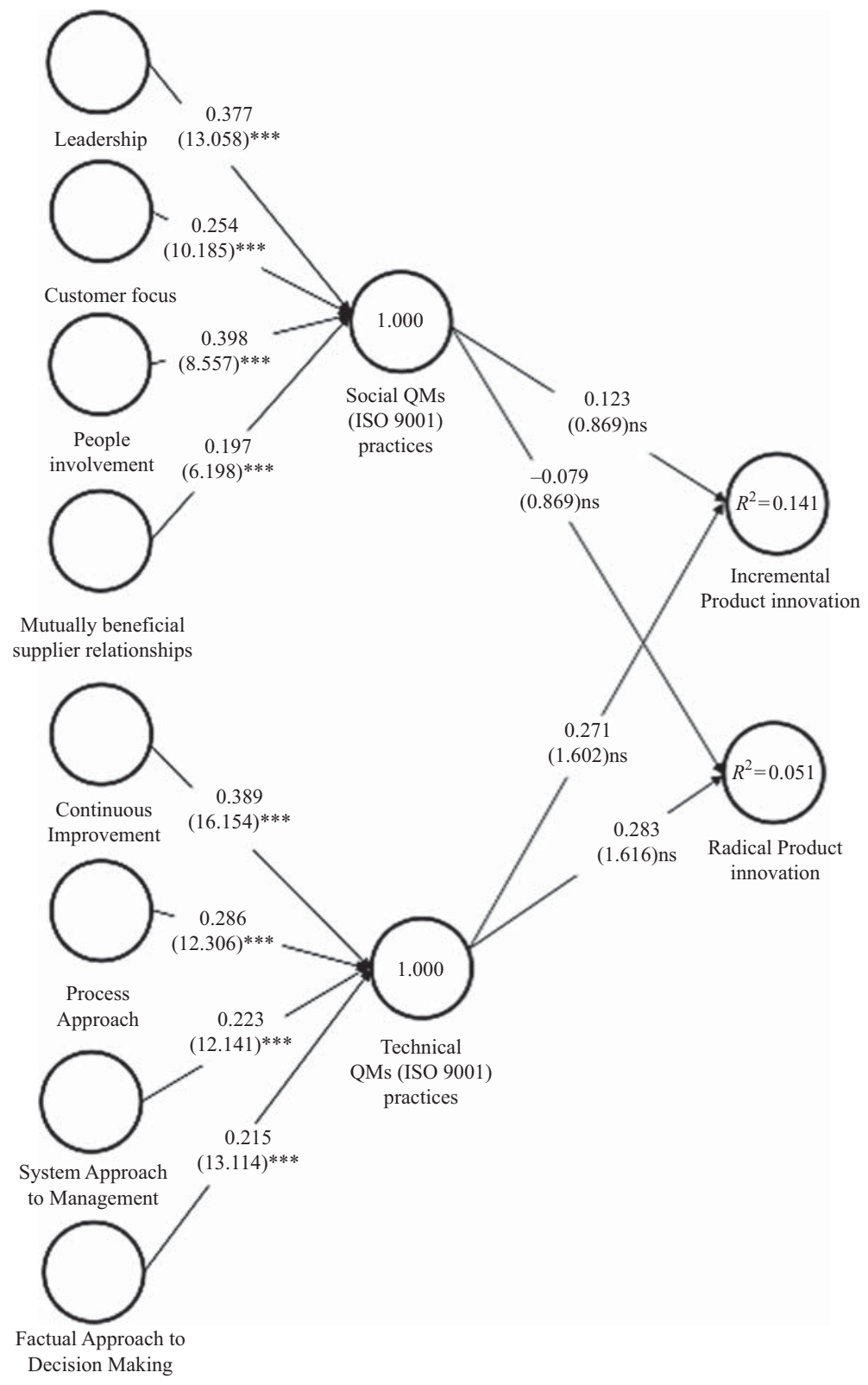

Notes: ${ }^{*} p<0.10: t$-value is greater than $1.65 ;{ }^{*} p<0.05: t$-value is greater than 1.96 ; $* * * p<0.01: t$-value is greater than 2.58
Figure 2.

Model (1) - the impact of social and technical QMs (9001) practices on incremental and radical product innovation

the variability in the incremental product innovation and 4 percent of the variability in the radical product innovation, which is largely less than the incremental product innovation. According to Cohen (1988), this demonstrates that QMs (ISO 9001) has a moderate role in explaining incremental product innovation beside a very weak role in explaining radical 
Figure 3.

Model (2) - the impact of the sociotechnical QM (9001) system on incremental and radical product innovation

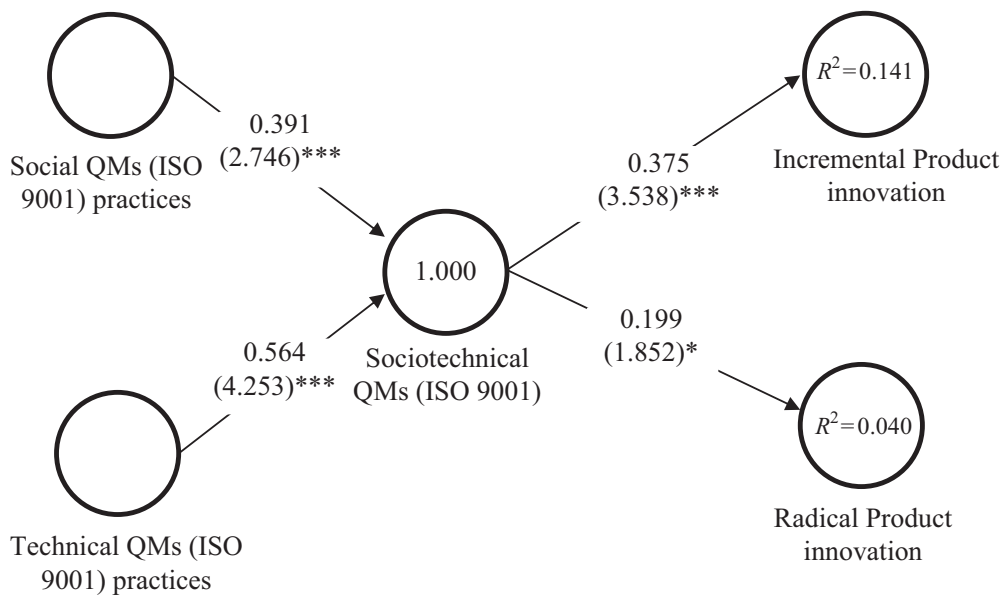

Notes: ${ }^{*} p<0.10: t$-value is greater than $1.65 ;{ }^{* *} p<0.05: t$-value is greater than 1.96 ; ${ }^{* * *} p<0.01: t$-value is greater than 2.58

product innovation. The second model presents a good model fit giving that the SRMR value is 0.090 which not exceed the recommended value of 0.10 (Henseler et al., 2014).

\section{Discussion and conclusion}

Quality and innovation are two complementary strategies that allow firms to face aggressive competition and sustain their competitive advantage. In spite of the amount of the literature about Quality and innovation, the relationship between these two strategies is still not deeply explored, and studies say nothing about the relationship between QMs (ISO 9001) practices and product innovation. From a sociotechnical perspective, the main purpose of this paper is to empirically investigate the relationship between QMS (ISO 9001) practices and product innovation. Therefore, this paper is a first attempt to study the impact of the social and technical QMs (ISO 9001) practices on incremental and radical product innovation. A PLS SEM analysis of data from 82 Moroccan certified ISO 9001 firm conducted us to support only two hypotheses among the six hypotheses of our research model.

Contrary to our expectations, we find that there is no significant relationship between the social practices of QMs (ISO 9001) and both incremental and radical product innovation. These results align with the study of Zeng et al. (2015), who found that soft QM has no direct impact on innovation performance. But they contradict theoretical views and empirical evidence which reported that social practices allow firms to be more innovative (Abrunhosa and Moura E Sá, 2008; Feng et al., 2006; Kanapathy et al., 2017; Moura E Sá and Abrunhosa, 2007; Perdomo-Ortiz et al., 2009; Prajogo and Sohal, 2004; Santos-Vijande and Álvarez-González, 2007; Song and Su, 2015; Thai Hoang et al., 2006). However, these are seemingly counter-intuitive and need to be interpreted with caution. A plausible theoretical explanation can be that the link between social practices and product innovation may not be in a simple direct linear form as tested in our study. Also, the social practices can be insufficient to support product innovation alone, and they need to be integrated with technical practices, which can play a mediating role in the relationship between social practices and product innovation (Kim et al., 2012; Zeng et al., 2015). On the other hand, a possible managerial explanation may be that Moroccan certified firms place more emphasis on the technical aspect to the detriment of the social aspect of ISO 9001. Some studies found 
that organizations rely more on instrumental tools and technical methods rather than the social practices (Pheng, 1993; Seymour and Low, 1990), because they are more popular in terms of their implementation (Lewis et al., 2006), and they can be more easily observable and exactly quantified in practice (Calvo-Mora et al., 2013; Gadenne and Sharma, 2009).

Meanwhile, our results show that QMs (ISO 9001) technical practices also have no significant relationship with incremental and radical product innovation. This can meet Song and $\mathrm{Su}$ (2015) findings that technical practices have an insignificant influence on new product development capabilities. And do not support López-Mielgo et al. (2009) who indicate that technical practices will hamper product innovation but only when it is radical. These practices introduce more formalization, standardization and low variability in the organizational process which stifles the spirit of innovation within the organization (Beasley, 1992). By nature, the development of incremental or radical product innovation is a creative and iterative design that generates new ideas through organizational processes variations (Sethi and Sethi, 2009). Indeed, reducing process variations may, in fact, reduce the emergence of new ideas (Song and Su, 2015), and get employees trapped into current activities that are workable and convince their work routines without being open for change (Prajogo and Sohal, 2001). Furthermore, firms when relying more on technical practices can just improve the quality of their product, however, producing a high-product quality may not necessarily lead to incremental and radical product innovation since it is found that the technical QMs (ISO 9001) are more correlated to product quality (Feng et al., 2006; Prajogo and Sohal, 2006a, b; Prajogo and Sohal, 2003, 2004). In fact, concentrating on technical practices does no longer appear to raise the achievement of product innovativeness beyond improved quality (Zeng et al., 2017).

Additionally, another possible explanation for the insignificant effect of social and technical QMs (ISO 9001) on incremental and radical product innovation can be the attitude of Moroccan innovative firms about the adoption of the QMs (ISO 9001). They are partially enthusiasts in their QMs (ISO 9001) implementation as they are more motivated by the external benefits of the ISO 9001 certification rather than internal ones. The external motivations steer the organization to focus on enhancing its quality reputation and reacting to the external pressures. That will not allow the optimization of the advantages that the organization can draw from the MQ (ISO 9001) because it will be implemented in a superficial way. "having a certificate is not the same as adopting the ISO 9001 standard" (Manders et al., 2016, p. 3), and do not lead to the same organizational efficacy. Consequently, such partial "quality enthusiasts" attitude transform the QMs to an "iron cage" that shuts the organization and undermine the effectiveness of the QMs (ISO 9001) (Boiral, 2003).

Authors claim that the contrary effect of QM on product innovation is possibly explained by the way of QM practices implementation, firms can be more oriented by social practices or more by technical practices (Martínez-Costa and Martínez-Lorente, 2008). According to our results above, we observe that being more oriented by some specific QM practices does not ensure incremental or radical product innovation. Thus, the confirmation of the $H 3 a$ and $H 3 b$ reveals an interesting insight that QMs (ISO 9001) positively and significantly affect incremental and radical product innovation, even if the impact is relatively weak for the later.

Our results might share particular similarities with Benner and Tushman (2002) who found that ISO 9001, through process management, is more adapted to increase the potential of exploitative innovations rather than explorative ones. Therefore, QMs (ISO 9001) is likely to better support firms' incremental product innovation once the implementation and management of its social and technical practices are well adjusted. In other words, firms that operate according to social and technical practices of QMs (ISO 9001) in a combinatory fashion successfully achieve incremental product innovation. Accordingly, Kafetzopoulos et al. (2013) and Pekovic and Galia (2009) found that top-quality level firms with effective 
implementation of the ISO 9001 standard is more innovative and introducing new products faster than major competitors do.

Nonetheless, QMs (ISO 9001) only shows partial support for radical product innovation. This result does not reject the potential role that QMS (ISO 9001) can play in radical product innovation; perhaps this role should be viewed longitudinally. That means QMs (ISO 9001) may have a minor significant short-term impact on radical product innovation before producing long-term benefits (Bourke and Roper, 2017). This weak impact could be contingent on other environmental or organizational factors. Blank and Naveh (2014) found that QM (ISO 9001), through quality climate, is significantly and positively associated with radical product innovation when firm establishes a high information exchange climate. Otherwise, the structure of the ISO 9001 standard and its tenet of continuous improvement philosophy made it incrementally oriented and do not largely favorite the development of radical product innovation. Moreover, through its intense internal focus, this standard partially encourages firms open innovation strategy required to develop radical innovation, or even negatively (Roldán Bravo et al., 2017). However, the implications of QMs (ISO 9001) for radical product innovation should not be completely rejected, we argue that the standard, until now, can facilitate this type of innovation only just in a very constrained manner.

Our findings support the idea that the system is a whole rather than a sum of simple practices arranged together. They are generally consistent with studies that used the STS in QM and confirm that the implementation of both the social and technical practices allows firms to achieve the best performance. Cua et al. (2001) showed that the joint optimization of both the socially oriented common practices and the technically oriented basic TQM, JIT and TPM techniques is necessary for achieving performance. Ho et al., (2001) found that the interdependent nature of TQM, between social and technical practices, positively affects quality performance. Results of $\mathrm{Zu}$ (2009) also indicates that the social and technical QM practices interact and both positively influence quality performance. Considering product innovation as an outcome to explain, we have already identified that the social and technical aspects of QMs (ISO 9001) are symbiotic, must be designed jointly without taking a logical superiority over each other. When we test the direct impact of social and technical practices on incremental and radical product innovation, the relationships were not significant. While, when the two are integrated to form a sociotechnical QMs (ISO 9001), we detect a positive and significant association between QMs (ISO 9001) as a whole with incremental and radical product innovation. These explicitly address that product innovation required the implementation of a sociotechnical QMs (ISO 9001) that proficiently fit its two social and technical subsystems.

\section{Theoretical and managerial implications}

The contribution of this paper can be twofold. Theoretically, our study is the first research that is especially interested in the social and technical practices of QMs (ISO 9001) and their relations with incremental and radical product innovation. In fact, we contribute to the field of sociotechnical systems design by using the sociotechnical thinking in the area of quality management as authors (e.g. Davis et al., 2014) have suggested it. By doing so, this study shows that QMs (ISO 9001), similarly to TQM, is a multidimensional management framework that encompasses both social and technical subsystems differently to certain authors who consider QMs (ISO 9001) from a very narrow point of view by reducing it as a whole to a technical practice (Bourke and Roper, 2017; Prajogo and Sohal, 2004). However, our findings contrast with the studies on the relationship between TQM and innovation that generally show that social and technical TQM practices have a differential impact on incremental or radical product innovation. This study reveals that social and technical QMs 
(ISO 9001) generally have a synergistic effect on product innovation, with a particular emphasis on incremental product innovation.

From a managerial perspective, our results provide valuable implications for firms from developing countries like Morocco engaged in QMs (ISO 9001) that seek to develop product innovations. The generalization of the results to other countries with lower middle income like Morocco may be possible, as North African, sub-Saharan and Middle Eastern economies. However, some contextual factors should be integrated into our conceptual model, considering the existence of socio-cultural differences in QM practices (ISO 9001) implementation and innovation. In that sense, our study fills one the several literature gaps in research in the area of QM which is the application of QM systems in developing countries. By showing that their product innovations can depend on the way they adopt QMs (IS0 9001), managers should first review the level of the implementation of their quality management system, correcting its anomalies and ensure that both social and technical practices achieve a high level of integration without allowing some quality practices taking over the others. For instance, an inefficient integration of social practices will deteriorate the effectiveness of the technical practices, and vice versa, then that will condemn firm's innovation capacity that can be achieved from the overall QM (ISO 9001) implementation (Kaynak, 2003). In fact, a high level of integration will enhance the efficacy of their product innovation process. Because the social practices are more needed to help some functions like the research and development (R\&D) in the ideation phase of the process whilst the technical practices are required to assist production at the new product industrialization phase (Prajogo and Sohal, 2004; Watson and Rao Korukonda, 1995). This can be more pronounced for incremental product innovation. While concerning radical product innovation, managers should establish an information exchange climate that facilitates to QMs (ISO 9001) not only the exploitation of current knowledge but also the search for new knowledge through novel approaches to problem solving that are required to producing radical product innovations (Blank and Naveh, 2014).

\section{Limitations and future research}

Our study admits some limitations. First, the small sample size weakened the significance of the results and the use of cross-sectional data limited our ability to determine the causal effect of QMs (ISO 9001) practices on incremental and radical product innovation. This study must be replicated on a large sample size with a panel data to determine the effect of QMs (ISO 9001) in short and large term since the benefits of the implementation of QM practices cannot be reached instantly, also taking into consideration the experience effect of QM implementation that may moderate its impact on product innovation. This impact can also be moderated by some other important variables, especially the firm's internal and external motivations for certification, in addition to firm size and the type of industry.

Second, the questionnaire was largely filled out by the quality managers. The subjective nature of the data collected through these respondents may imply the risk of a social desirability bias as quality managers are overly positive about their QM systems and its impacts. In addition to the quality managers, collecting data from the marketing and R\&D managers will help to better understand the impact of the QM (ISO 9001) on product innovation.

Third, our research just catches that there is a synergistic effect of social and technical QMs (ISO 9001) practices on product innovation but do not deeply explain how the synergy between the two categories of practices occurs in product innovation. Researchers are invited to investigate how innovative firms manage these social and technical aspects of QMs (ISO 9001) at the new product development project level. On the other hand, we suggest future research to introduce the complementary role that some firm's strategic orientation, 
e.g. market orientation or entrepreneurial orientation, can play in supporting QMs (ISO 9001) impact on incremental and radical product innovation and, in turn, enhance financial performance (El Manzani et al., 2016, 2017). Finally, the effective role of the new ISO 9001: 2015 QMs in product innovation must be investigated, as the majority of the firms in our sample have not yet switched from the ISO 9001:2008 to the new version.

\section{References}

Abdallah, A.B. (2013), "The influence of 'soft' and 'hard' total quality management (TQM) practices on total productive maintenance (TPM) in Jordanian manufacturing companies", International Journal of Business and Management, Vol. 8 No. 21, pp. 1-13.

Abdullah, M.M.B., Uli, J. and Tarí, J.J. (2009), "The relationship of performance with soft factors and quality improvement", Total Qualitv Management \& Business Excellence, Vol. 20 No. 7, pp. 735-748.

Abrunhosa, A. and Moura E Sá, P. (2008), "Are TQM principles supporting innovation in the Portuguese footwear industry?”, Technovation, Vol. 28 No. 4, pp. 208-221.

Ahmed, P.K. (1998), "Culture and climate for innovation", European Iournal of Innovation Management, Vol. 1 No. 1, pp. 30-43.

Al-Refaie, A., Ghnaimat, O. and Li, M.H. (2012), "Effects of ISO 9001 certification and KAAE on performance of Jordanian firms", Jordan Journal of Mechanical and Industrial Engineering, Vol. 6 No. 1 , pp. $45-53$.

Anderson, J.C. and Gerbing, D.W. (1988), "Structural equation modeling in practice: a review and recommended two-step approach", Psvchological Bulletin, Vol. 103 No. 3, pp. 411-423.

Anderson, J.C., Rungtusanatham, M., Schroeder, R.G. and Devaraj, S. (1995), "A path analytic model of a theory of quality management underlying the deming management method: preliminary empirical findings", Decision Sciences, Vol. 26 No. 5, pp. 637-658.

Anderson, S.W., Daly, J.D. and Johnson, M.F. (2009), "Why firms seek ISO 9000 certification: regulatory compliance or competitive advantage?", Production and Operations Management, Vol. 8 No. 1, pp. 28-43.

Antony, J., Leung, K., Knowles, G. and Gosh, S. (2002), "Critical success factors of TQM implementation in Hong Kong industries", International Journal of Quality \& Reliability Management, Vol. 19 No. 5, pp. 551-566.

Appelbaum, S.H. (1997), "Socio-technical systems theory: an intervention strategy for organizational development", Management Decision, Vol. 35 No. 6, pp. 452-463.

Arauz, R. and Suzuki, H. (2004), "ISO 9000 performance in Japanese industries", Total Quality Management and Business Excellence, Vol. 15 No. 1, pp. 3-33.

Argyris, C. and Schön, D. (1978), Organizational Learning: A Theory of Action Approach, Addision Wesley, Reading, MA.

Arnold, T.J., Fang, E. (Er) and Palmatier, R.W. (2011), "The effects of customer acquisition and retention orientations on a firm's radical and incremental innovation performance", Journal of the Academv of Marketing Science, Vol. 39 No. 2, pp. 234-251.

Bakotić, D. and Rogošić, A. (2015), "Employee involvement as a key determinant of core quality management practices", Total Qualitv Management \& Business Excellence, Vol. 28 Nos 11-12, pp. 1209-1226.

Baldwin, J.R. and Johnson, J. (1996), "Business strategies in more- and less-innovative firms in Canada", Research Policy, Vol. 25 No. 5, pp. 785-804.

Barclay, D., Higgins, C. and Hompson, R. (1995), “The partial least squares (PLS) approach to causal modeling: personal computer adoption and use an illustration", Technology Studies, Vol. 2 No. 2 , pp. 285-309. 
Bayo-Moriones, A., Merino-Díaz-De-Cerio, J., Antonio Escamilla-De-León, S. and Mary Selvam, R. (2011), "The impact of ISO 9000 and EFQM on the use of flexible work practices", International Journal of Production Economics, Vol. 130 No. 1, pp. 33-42.

Beasley, K. (1992), "Total quality management (TQM) in research and development", Microelectronic Engineering $v 19$ n 1-4 Sep 1992. p 67-74, Vol. 6 No. 1, pp. 26-34.

Becker, J.M., Klein, K. and Wetzels, M. (2012), "Hierarchical latent variable models in PLS-SEM: guidelines for using reflective-formative type models", Long Range Planning, Vol. 45 Nos 5-6, pp. 359-394.

Benner, M. j and Tushman, M. (2002), "Process management and technological innovation: a longitudinal study of the photography and paint industries", Administrative Science Quarterlv, Vol. 47 No. 4, pp. 676-706.

Benner, M.J. and Tushman, M.L. (2003), "Exploitation, exploration, and process management: the productivity dilemma revisited", Academv of Management Review, Vol. 28 No. 2, pp. 238-256.

Blank, T.-H. and Naveh, E. (2014), "Do quality and innovation compete against or complement each other? The moderating role of an information exchange climate", The Qualitv Management Iournal, Vol. 21 No. 2, pp. 4, 6-16.

Boiral, O. (2003), "ISO 9000: outside the iron cage”, Organization Science, Vol. 14 No. 6, pp. 720-737.

Bostrom, R.P. and Heinen, J.S. (1977a), "MIS problems and failures: a socio-technical perspective, part II: the application of socio-technical theory", MIS Quarterly, Vol. 1 No. 4, pp. 11-28.

Bostrom, R.P. and Heinen, J.S. (1977b), "MIS problems and failures: a socio-technical perspective. part i: the causes", MIS Quarterly, Vol. 1 No. 3, pp. 17-32.

Bourke, J. and Roper, S. (2017), "Innovation, quality management and learning: short-term and longer-term effects", Research Policy, Vol. 46 No. 8, pp. 1505-1518.

Bowen, D.E. and Lawler, E.E. (1992), "Total quality-oriented human resources management", Organizational Dynamics, Vol. 20 No. 4, pp. 29-41.

Bozdogan, K., Deyst, J., Hoult, D. and Lucas, M. (1998), "Architectural innovation in product development through early supplier integration”, R\&D Management, Vol. 28 No. 3, pp. 163-173.

Brislin, R.W. (1970), "Back-translation for cross-cultural research", Journal of Cross-Cultural Psychology, Vol. 1 No. 3, pp. 185-216.

Calvo-Mora, A., Picón, A., Ruiz, C. and Cauzo, L. (2013), "The relationships between soft-hard TQM factors and key business results", International Iournal of Operations \& Production Management, Vol. 34 No. 1, pp. 115-143.

Carson, K.P. and Stewart, G.L. (1996), "Job analysis and the sociotechnical approach to quality: a critical examination”, Journal of Quality Management, Vol. 1 No. 1, pp. 49-65.

Castillo-Rojas, S.M., Casadesús, M., Karapetrovic, S., Coromina, L. and Heras, I. (2012), "Is implementing multiple management system standards a hindrance to innovation?", Total Quality Management and Business Excellence, Vol. 23 Nos 9-10, pp. 1075-1088.

Chang, W. and Taylor, S.A. (2016), "The effectiveness of customer participation in new product development: a meta-analysis", Lournal of Marketing, Vol. 80 No. 1, pp. 47-64.

Cherns, A. (1987), "Principles of sociotechnical design revisted", Human Relations, Vol. 40 No. 3, pp. 153-161.

Chin, W.W. (1998), "The partial least squares approach for structural equation modeling", in Marcoulides, G.A. (Ed.), Methodology for Business and Management, Modern Methods for Business Research, Lawrence Erlbaum Associates Publishers, Mahwah, NJ, pp. 295-336.

Chin, W.W. (2010), "How to write up and report PLS analyses", in Vinzi, V.E., Chin, W.W., Henseler, J. and Wang, H. (Eds), Handbook of Partial Least Squares, Springer Berlin Heidelberg, Berlin, Heidelberg, pp. 655-690.

Cho, H.-J. and Pucik, V. (2005), "Relationship between innovativeness, quality, growth, profitability, and market value", Strategic Management Journal, Vol. 26 No. 6, pp. 555-575. 
Cho, Y.S., Jung, J.Y. and Linderman, K. (2017), "The QM evolution: behavioral quality management as a firm's strategic resource", International Journal of Production Economics, Vol. 191, September, pp. 233-249.

Cohen, J. (1988), Statistical Power Analysis for the Behavioral Sciences, 2nd ed., Lawrence Erlbaum Associates, Hillsdale, MI.

Cole, R.E. and Matsumiya, T. (2007), "Too much of a good thing? quality as an impediment to innovation”, California Management Review, Vol. 50 No. 1, pp. 77-93.

Craig, C.S. and Douglas, S.P. (2000), "Configural advantage in global markets", Journal of International Marketing, Vol. 8 No. 1, pp. 6-26.

Cua, K.O., McKone, K.E. and Schroeder, R.G. (2001), "Relationships between implementation of TQM, JIT, and TPM and manufacturing performance", Journal of Operations Management, Vol. 19 No. 6, pp. 675-694.

Dale, B. (2015), "Total quality management”, in Cooper, C.L. (Ed.), Wiley Encyclopedia of Management, John Wiley \& Sons, Ltd, Chichester, pp. 1-4.

Damanpour, F. (1991), "Organizational innovation: a meta-analysis of effects of determinants and moderators", Academy of Management Journal, Vol. 34 No. 3, pp. 555-590.

Davis, M.C., Challenger, R., Jayewardene, D.N.W. and Clegg, C.W. (2014), "Advancing socio-technical systems thinking: a call for bravery”, Applied Ergonomics, Vol. 45 No. 2, pp. 171-180.

Dean, J.W. and Susman, G.I. (1989), "Organizing for manufacturable design”, Harvard Business Review, Vol. 67 No. 1, pp. 28-36.

Delić, M., Radlovački, V., Kamberović, B., Maksimović, R. and Pečujlija, M. (2014), "Examining relationships between quality management and organisational performance in transitional economies", Total Quality Management \& Business Excellence, Vol. 25 Nos 3-4, pp. 367-382.

Dick, G.P.M. (2000), "ISO 9000 certification benefits, reality or myth?", The TQM Magazine, Vol. 12 No. 6, pp. 365-371.

Douglas, S.P. and Craig, C.S. (2007), "Collaborative and iterative translation: an alternative approach to back translation”, Journal of International Marketing, Vol. 15 No. 1, pp. 30-43.

Dow, D., Samson, D. and Ford, S. (2009), "Exploding the myth: do all quality management practices contribute to superior quality performance?", Production and Operations Management, Vol. 8 No. 1, pp. 1-27.

Eason, K. (2014), "Afterword: the past, present and future of sociotechnical systems theory", Applied Ergonomics, Vol. 45 No. 2 Part A, pp. 213-220.

El Manzani, Y., Sidmou, M.L. and Cegarra, J.J. (2016), "L'impact de la synergie entre management de la qualité et capacités marketing sur l'innovation produit: proposition d'un cadre conceptuel", International Journal of Innovation and Applied Studies, Vol. 16 No. 4, pp. 787-798.

El Manzani, Y., Sidmou, M.L. and Cegarra, J.J. (2017), “A conceptual framework of the relationship between total quality management, corporate social responsibility, innovation capability, and financial performance", International Journal of Quality and Innovation, Vol. 3 Nos 2/3/4, pp. 188-208.

Enkel, E. and Gassmann, O. (2010), "Creative imitation: exploring the case of cross-industry innovation", R\&D Management, Vol. 40 No. 3, pp. 256-270.

Enkel, E., Heil, S., Hengstler, M. and Wirth, H. (2017), "Exploratory and exploitative innovation: to what extent do the dimensions of individual level absorptive capacity contribute?", Technovation, Vol. 60-61, February, pp. 29-38.

Feng, J., Prajogo, D.I., Tan, K.C. and Sohal, A.S. (2006), "The impact of TQM practices on performance: a comparative study between Australian and Singaporean organizations", European Journal of Innovation Management, Vol. 9 No. 3, pp. 269-278.

Flynn, B.B. (1994), "The relationship between quality management practices, infrastructure and fast product innovation”, Benchmarking for Quality Management \& Technology, Vol. 1 No. 1, pp. $48-64$. 
Flynn, B.B., Schroeder, R.G. and Sakakibara, S. (1994), "A framework for quality management research and an associated measurement instrument", Journal of Operations Management, Vol. 11 No. 4, pp. 339-366.

Flynn, B.B., Schroeder, R.G. and Sakakibara, S. (1995), "The impact of quality management practices on performance and competitive advantage”, Decision Sciences, Vol. 26 No. 5, pp. 659-691.

Fornell, C. and Larcker, D.F. (1981), "Evaluating structural equation models with unobservable variables and measurements error", Journal of Marketing Research, Vol. 18 No. 4, pp. 39-50.

Fotopoulos, C.B. and Psomas, E.L. (2009), "The impact of 'soft' and 'hard' TQM elements on quality management results”, International Journal of Quality \& Reliability Management, Vol. 26 No. 2, pp. 150-163.

Gadenne, D. and Sharma, B. (2009), "An investigation of the hard and soft quality management factors of Australian SMEs and their association with firm performance", International Journal of Quality \& Reliability Management, Vol. 26 No. 9, pp. 865-880.

Gotzamani, K.D. and Tsiotras, G.D. (2002), "The true motives behind ISO 9000 certification", International Journal of Quality \& Reliability Management, Vol. 19 No. 2, pp. 151-169.

Griffith, T.L. and Dougherty, D.J. (2001), "Beyond socio-technical systems: introduction to the special issue", Journal of Engineering and Technology Management - JET-M, Vol. 18 Nos 3-4, pp. 207-218.

Griffith, T.L., Fuller, M.A. and Northcraft, G.B. (1998), "Facilitator influence in group support systems: intended and unintended effects", Information Systems Research, Vol. 9 No. 1, pp. 20-36.

Guimarães, J.C.F., de Severo, E.A., Dorion, E.C.H., Coallier, F. and Olea, P.M. (2016), "The use of organisational resources for product innovation and organisational performance: a survey of the Brazilian furniture industry", International Journal of Production Economics, Vol. 180, October, pp. 135-147.

Hair, J.J.F., Ringle, C.M. and Sarstedt, M. (2011), "PLS-SEM: indeed a silver bullet", The Journal of Marketing Theory and Practice, Vol. 19 No. 2, pp. 139-152.

Hair, J.J.F., Sarstedt, M., Ringle, C.M. and Mena, J.A. (2012), “An assessment of the use of partial least squares structural equation modeling in marketing research", Journal of the Academy of Marketing Science, Vol. 40 No. 3, pp. 414-433.

Hair, J.J.F., Sarstedt, M., Hopkins, L. and Kuppelwieser, G.V. (2014), "Partial least squares structural equation modeling (PLS-SEM)”, European Business Review, Vol. 26 No. 2, pp. 106-121.

Hair, J.J.F., Hollingsworth, C.L., Randolph, A.B. and Chong, A.Y.L. (2017), "An updated and expanded assessment of PLS-SEM in information systems research", Industrial Management \& Data Systems, Vol. 117 No. 3, pp. 442-458.

Hendrick, H.W. (1997), "Organizational design and macroergonomics”, in Salvendy, G. (Ed.), Handbook of Human Factors and Ergonomics, 2nd ed., John Wiley, New York, NY, pp. 594-636.

Henseler, J. (2017), "Partial least squares path modeling”, in Bijmolt, T.H., Leeflang, P.S.H., Pauwels, K.H. and Wieringa, J.E. (Eds), Advanced Methods for Modeling Markets, Springer, Cham, pp. 361-381.

Henseler, J., Ringle, C.M. and Rudolf, R.S. (2009), "The use of partial least squares path modeling in international marketing", in Sinkovics, R.R. and Pervez, N.G. (Eds), Advances in International Marketing, Emerald Group Publishing, Bingley, pp. 277-319.

Henseler, J., Dijkstra, T.K., Sarstedt, M., Ringle, C.M., Diamantopoulos, A., Straub, D.W., Ketchen, D.J., Hair, J.F., Hult, G.T.M. and Calantone, R.J. (2014), "Common beliefs and reality about PLS", Organizational Research Methods, Vol. 17 No. 2, pp. 182-209.

Ho, D.C.K., Duffy, V.G. and Shih, H.M. (2001), "Total quality management: an empirical test for mediation effect", International Journal of Production Research, Vol. 39 No. 3, pp. 529-548.

Hu, L. and Bentler, P.M. (1999), "Cutoff criteria for fit indexes in covariance structure analysis: conventional criteria versus new alternatives", Structural Equation Modeling: A Multidisciplinary Journal, Vol. 6 No. 1, pp. 1-55. 
Huarng, F. (1998), "Integrating ISO 9000 with TQM spirits: a survey", Industrial Management \& Data Systems, Vol. 98 No. 8, pp. 373-379.

Huo, B., Han, Z. and Prajogo, D. (2014), "The effect of ISO 9000 implementation on flow management", International Journal of Production Research, Vol. 52 No. 21, pp. 6467-6481.

Jayaram, J., Ahire, S.L. and Dreyfus, P. (2010), "Contingency relationships of firm size, TQM duration, unionization, and industry context on TQM implementation - a focus on total effects", Journal of Operations Management, Vol. 28 No. 4, pp. 345-356.

Jayawarna, D. and Pearson, A.W. (2001), "The role of ISO 9001 in managing the quality of R\&D activities", The TQM Magazine, Vol. 13 No. 2, pp. 120-128.

Kafetzopoulos, D., Gotzamani, K. and Gkana, V. (2015), "Relationship between quality management, innovation and competitiveness. evidence from greek companies", Journal of Manufacturing Technology Management, Vol. 26 No. 8, pp. 1177-1200.

Kafetzopoulos, D., Gotzamani, K. and Psomas, E. (2013), "Quality systems and competitive performance of food companies", Benchmarking: An International Journal, Vol. 20 No. 4, pp. 463-483.

Kanapathy, K., Bin, C.S., Zailani, S. and Aghapour, A.H. (2017), "The impact of soft TQM and hard TQM on innovation performance: the moderating effect of organisational culture", International Journal of Productivity and Quality Management, Vol. 20 No. 4, p. 429.

Katz, D. and Kahn, R.L. (1978), The Social Psychology of Organizations, 2nd ed., Wiley, New York, NY.

Kaynak, H. (2003), "The relationship between total quality management practices and their effects on firm performance", Journal of Operations Management, Vol. 21 No. 4, pp. 405-435.

Khan, B.A. and Naeem, H. (2018), "Measuring the impact of soft and hard quality practices on service innovation and organisational performance", Total Quality Management \& Business Excellence, Vol. 29 Nos 11-12, pp. 1402-1426.

Kim, D.Y., Kumar, V. and Kumar, U. (2012), "Relationship between quality management practices and innovation”, Journal of Operations Management, Vol. 30 No. 4, pp. 295-315.

Kochan, T.A., Gittell, J.H. and Lautsch, B.A. (1995), "Total quality management and human resource systems: an international comparison", The International Journal of Human Resource Management, Vol. 6 No. 2, pp. 201-222.

Koukoulaki, T. (2014), "The impact of lean production on musculoskeletal and psychosocial risks: an examination of sociotechnical trends over 20 years", Applied Ergonomics, Vol. 45 No. 2 Part A, pp. 198-212.

Lakhal, L., Pasin, F. and Limam, M. (2006), "Quality management practices and their impact on performance", International Journal of Quality \& Reliability Management, Vol. 23 No. 6, pp. 625-646.

Lau, A.K.W., Tang, E. and Yam, R.C.M. (2010), "Effects of supplier and customer integration on product innovation and performance: empirical evidence in Hong Kong manufacturers",Journal of Product Innovation Management, Vol. 27 No. 5, pp. 761-777.

Lee, P.K.C., To, W.M. and Yu, B.T.W. (2009), "The implementation and performance outcomes of ISO 9000 in service organizations", International Journal of Quality \& Reliability Management, Vol. 26 No. 7, pp. 646-662.

Lee, V.H., Ooi, K.B., Tan, B.I. and Chong, A.Y.L. (2010), "A structural analysis of the relationship between TQM practices and product innovation", Asian Journal of Technology Innovation, Vol. 18 No. 1, pp. 73-96.

Lewis, W.G., Fai Pun, K. and Lalla, T.R.M. (2006), "Empirical investigation of the hard and soft criteria of TQM in ISO 9001 certified small and medium-sized enterprises", International Journal of Quality \& Reliability Management, Vol. 23 No. 8, pp. 964-985.

Lin, L.-H. and Lu, I.-Y. (2006), "Product quality as a determinant of product innovation: an empirical analysis of the global automotive industry", Total Quality Management \& Business Excellence, Vol. 17 No. 2, pp. 141-147. 
López-Mielgo, N., Montes-Peón, J.M. and Vázquez-Ordás, C.J. (2009), “Are quality and innovation management conflicting activities?”, Technovation, Vol. 29 No. 8, pp. 537-545.

McAdam, R. (2004), "Knowledge creation and idea generation: a critical quality perspective", Technovation, Vol. 24 No. 9, pp. 697-705.

McAdam, R., Armstrong, G. and Kelly, B. (1998), "Investigation of the relationship between total quality and innovation: a research study involving small organisations", European Journal of Innovation Management, Vol. 1 No. 3, pp. 139-147.

Madanmohan, T.R. (2005), "Incremental technical innovations and their determinants", International Journal of Innovation Management, Vol. 9 No. 4, pp. 481-510.

Magd, H. and Curry, A. (2003), "An empirical analysis of management attitudes towards ISO 9001:2000 in Egypt”, The TQM Magazine, Vol. 15 No. 6, pp. 381-390.

Magd, H., Kadasah, N. and Curry, A. (2003), "ISO 9000 implementation: a study of manufacturing companies in Saudi Arabia", Managerial Auditing Journal, Vol. 18 No. 4, pp. 313-322.

Manders, B., De Vries, H.J. and Blind, K. (2016), "ISO 9001 and product innovation: a literature review and research framework", Technovation, Vol. 48-49, pp. 41-55.

Mangiarotti, G. and Riillo, A.F.C. (2014), "Standards and innovation in manufacturing and services: the case of ISO 9000", International Journal of Quality \& Reliability Management, Vol. 31 No. 4, pp. $435-454$.

Manz, C.C. and Stewart, G.L. (1997), "Attaining flexible stability by integrating total quality management and socio-technical systems theory", Organization Science, Vol. 8 No. 1, pp. 59-70.

March, J.G. (1991), "Exploration and exploitation in organizational learning", Organization Science, Vol. 2 No. 1, pp. 71-87.

Martínez-Costa, M. and Martínez-Lorente, A.R. (2008), "Does quality management foster or hinder innovation? An empirical study of Spanish companies", Total Quality Management \& Business Excellence, Vol. 19 No. 3, pp. 209-221.

Martínez-Costa, M., Choi, T.Y., Martínez, J.A. and Martínez-Lorente, A.R. (2009), “ISO 9000/1994, ISO 9001/2000 and TQM: the performance debate revisited", Journal of Operations Management, Vol. 27 No. 6, pp. 495-511.

Menguc, B., Auh, S. and Yannopoulos, P. (2014), "Customer and supplier involvement in design: the moderating role of incremental and radical innovation capability", Journal of Product Innovation Management, Vol. 31 No. 2, pp. 313-328.

Miller, R. (1995), “Applying quality practices to research-and-development”, Research-Technology Management, Vol. 38 No. 2, pp. 47-54.

Molina, L.M., Lloréns-Montes, J. and Ruiz-Moreno, A. (2007), "Relationship between quality management practices and knowledge transfer", Journal of Operations Management, Vol. 25 No. 3, pp. 682-701.

Moura E Sá, P. and Abrunhosa, A. (2007), "The role of TQM practices in technological innovation: the portuguese footwear industry case", Total Quality Management \& Business Excellence, Vol. 18 Nos 1-2, pp. 57-66.

Naor, M., Goldstein, S.M., Linderman, K.W. and Schroeder, R.G. (2008), "The role of culture as driver of quality management and performance: infrastructure versus core quality practices", Decision Sciences, Vol. 39 No. 4, pp. 671-702.

Naveh, E. and Erez, M. (2004), "Innovation and attention to detail in the quality improvement paradigm”, Management Science, Vol. 50 No. 11, pp. 1576-1586.

Newman, A., Prajogo, D. and Atherton, A. (2016), "The influence of market orientation on innovation strategies", Journal of Service Theory and Practice, Vol. 26 No. 1, pp. 72-90.

Nowak, A. (1997), "Strategic relationship between quality management and product innovation", The Mid-Atlantic Journal of Business, Vol. 33 No. 2, p. 119. 
O'Connor, G.C. and Rice, M.P. (2013), "A comprehensive model of uncertainty associated with radical innovation”, Journal of Product Innovation Management, Vol. 30, Suppl. 1, pp. 2-18.

OECD (2005), Oslo Manual - Guidelines for Collecting and Interpreting Innovation Data, OECD, Paris.

Patyal, V.S. and Koilakuntla, M. (2017), "The impact of quality management practices on performance: an empirical study", Benchmarking: An International Journal, Vol. 24 No. 2, pp. 511-535.

Pekovic, S. and Galia, F. (2009), "From quality to innovation: evidence from two French employer surveys", Technovation, Vol. 29 No. 12, pp. 829-842.

Perdomo-Ortiz, J., González-Benito, J. and Galende, J. (2006), “Total quality management as a forerunner of business innovation capability", Technovation, Vol. 26 No. 10, pp. 1170-1185.

Perdomo-Ortiz, J., González-Benito, J. and Galende, J. (2009), "The intervening effect of business innovation capability on the relationship between total quality management and technological innovation”, International Journal of Production Research, Vol. 47 No. 18, pp. 5087-5107.

Petersen, K.J., Handfield, R.B. and Ragatz, G.L. (2005), "Supplier integration into new product development: coordinating product, process and supply chain design", Journal of Operations Management, Vol. 23 Nos 3-4, pp. 371-388.

Pheng, L.S. (1993), "The rationalization of quality in the construction industry: some empirical findings", Construction Management and Economics, Vol. 11 No. 4, pp. 247-259.

Pivka, M. and Ursic, D. (2002), "The impact of ISO 9001 certification process on Slovenian companies", Journal for East European Management Studies, Vol. 7 No. 1, pp. 27-45.

Powell, T. (1995), "Total quality management as competitive advantage: a review and empirical study", Strategic Management Journal, Vol. 16 No. 1, pp. 15-37.

Power, D. and Singh, P. (2007), "The e-integration dilemma: the linkages between Internet technology application, trading partner relationships and structural change", Journal of Operations Management, Vol. 25 No. 6, pp. 1292-1310.

Prajogo, D.I. and Sohal, A.S. (2001), "TQM and innovation: a literature review and research framework", Technovation, Vol. 21 No. 9, pp. 539-558.

Prajogo, D.I. and Sohal, A.S. (2003), "The relationship between TQM practices, quality performance, and innovation performance", International Journal of Quality \& Reliability Management, Vol. 20 No. 8, pp. 901-918.

Prajogo, D.I. and Sohal, A.S. (2004), "The multidimensionality of TQM practices in determining quality and innovation performance - an empirical examination", Technovation, Vol. 24 No. 6, pp. 443-453.

Prajogo, D.I. and Sohal, A.S. (2006a), "The integration of TQM and technology/R\&D management in determining quality and innovation performance”, Omega, Vol. 34 No. 3, pp. 296-312.

Prajogo, D.I. and Sohal, A.S. (2006b), "The relationship between organization strategy, total quality management (TQM), and organization performance - the mediating role of TQM", European Journal of Operational Research, Vol. 168 No. 1, pp. 35-50.

Prester, J. and Bozac, M. (2012), “Are innovative organizational concepts enough for fostering innovation?”, International Journal of Innovation Management, Vol. 16 No. 1, pp. 1250005-1-1250005-23.

Psomas, E. and Antony, J. (2015), "The effectiveness of the ISO 9001 quality management system and its influential critical factors in Greek manufacturing companies", International Journal of Production Research, Vol. 53 No. 7, pp. 2089-2099.

Quazi, H.A. and Padibjo, S.R. (1997), "A journey toward total quality management through ISO 9000 certification - a study on small- and medium-sized enterprises in Singapore", International Journal of Quality \& Reliability Management, Vol. 15 No. 5, pp. 489-508.

Rahman, S. and Bullock, P. (2005), "Soft TQM, hard TQM, and organisational performance relationships: an empirical investigation”, Omega, Vol. 33 No. 1, pp. 73-83.

Ravichandran, T. and Rai, A. (2000), "Quality management in systems development: an organizational system perspective”, MIS Quarterly, Vol. 24 No. 3, pp. 381-415. 
Refaie, A. Al, Ghnaimat, O. and Ko, J.H. (2011), "The effects of quality management practices on customer satisfaction and innovation: a perspective from Jordan", International Journal of Productivity and Quality Management, Vol. 8 No. 4, pp. 398-415.

Reinartz, W., Haenlein, M. and Henseler, J. (2009), "An empirical comparison of the efficacy of covariance-based and variance-based SEM", International Journal of Research in Marketing, Vol. 26 No. 4, pp. 332-344.

Ringle, C.M., Wende, S. and Will, A. (2005), "SmartPLS 2.0", University of Hamburg, available at: https://doi.org/citeulike-article-id:10083551 (accessed August 8, 2017).

Ringle, C.M., Sarstedt, M., Mitchell, R. and Gudergan, S.P. (2018), "Partial least squares structural equation modeling in HRM research", The International Journal of Human Resource Management, pp. 1-27.

Roldán Bravo, M.I., Lloréns Montes, F.J. and Ruiz Moreno, A. (2017), "Open innovation and quality management: the moderating role of interorganisational IT infrastructure and complementary learning styles", Production Planning and Control, Vol. 28 No. 9, pp. 744-757.

Roldán, J.L. and Sánchez-Franco, M.J. (2012), "Variance-based structural equation modeling: guidelines for using partial least squares in information systems research”, in Mora, M., Gelman, O., Steenkamp, A.L. and Raisinghani, M. (Eds), Research Methodologies, Innovations and Philosophies in Software Systems Engineering and Information Systems, IGI Global, pp. 193-221.

Sadikoglu, E. and Zehir, C. (2010), "Investigating the effects of innovation and employee performance on the relationship between total quality management practices and firm performance: an empirical study of Turkish firms", International Journal of Production Economics, Vol. 127 No. 1, pp. 13-26.

Samson, D. and Terziovski, M. (1999), "Relationship between total quality management practices and operational performance", Journal of Operations Management, Vol. 17 No. 4, pp. 393-409.

Santos-Vijande, M.L. and Álvarez-González, L.I. (2007), "Innovativeness and organizational innovation in total quality oriented firms: the moderating role of market turbulence", Technovation, Vol. 27 No. 9, pp. 514-532.

Saraph, J.V., Benson, P.G. and Schroeder, R.G. (1989), "An instrument for measuring the critical factors of quality management”, Decision Sciences, Vol. 20 No. 4, pp. 810-829.

Sethi, R. and Sethi, A. (2009), "Can quality-oriented firms develop innovative new products?", Journal of Product Innovation Management, Vol. 26 No. 2, pp. 206-221.

Seymour, D. and Low, S.P. (1990), "The quality debate", Construction Management and Economics, Vol. 8 No. 1, pp. 13-29.

Shah, R. and Ward, P.T. (2007), "Defining and developing measures of lean production", Journal of Operations Management, Vol. 25 No. 4, pp. 785-805.

Shani, A.B. and Mitki, Y. (1996), "Reengineering, total quality management and sociotechnical systems approaches to organizational change: towards an eclectic approach?", Journal of Quality Management, Vol. 1 No. 1, pp. 131-145.

Singh, P.J. and Smith, A.J.R. (2004), "Relationship between TQM and innovation: an empirical study", Journal of Manufacturing Technology Management, Vol. 15 No. 5, pp. 394-401.

Sitkin, S.B. and Sutcliffe, K.M. (1994), "Distinguishing control from learning in total quality management: a contingency perspective", Academy of Management Review, Vol. 19 No. 3, pp. 537-564.

Slater, S.F. and Narver, J.C. (1998), "Customer-led and market-oriented: let's not confuse the two", Strategic Management Journal, Vol. 19 No. 10, pp. 1001-1006.

Song, M. and Thieme, J. (2009), "The role of suppliers in market intelligence gathering for radical and incremental innovation", Journal of Product Innovation Management, Vol. 26 No. 1, pp. 43-57. 
Song, Y. and Su, Q. (2015), "The relationship between quality management and new product development: evidence from China”, Operations Management Research, Vol. 8 Nos 1-2, pp. 1-14.

Sousa, R. and Voss, C.A. (2002), "Quality management re-visited: a reflective review and agenda for future research”, Journal of Operations Management, Vol. 20 No. 1, pp. 91-109.

Spencer, B.A. (1994), "Models of organization and total quality management: a comparison and critical evaluation”, The Academy of Management Review, Vol. 19 No. 3, pp. 446-471.

Tang, H.K. (1998), "An inventory of organizational innovativeness", Technovation, Vol. 19 No. 1, pp. 41-51.

Tarí, J.J., Molina, J.F. and Castejón, J.L. (2007), “The relationship between quality management practices and their effects on quality outcomes", European Journal of Operational Research, Vol. 183 No. 2, pp. 483-501.

Terziovski, M. and Guerrero, J. (2014), "ISO 9000 quality system certification and its impact on product and process innovation performance", International Journal of Production Economics, Vol. 158, pp. 197-207.

Thai Hoang, D., Igel, B. and Laosirihongthong, T. (2006), "The impact of total quality management on innovation", International Journal of Quality \& Reliability Management, Vol. 23 No. 9, pp. 1092-1117.

Trist, E.L. and Bamforth, K.W. (1951), "Some social and psychological consequences of the longwall method of coal-getting: an examination of the psychological situation and defences of a work group in relation to the social structure and technological content of the work system", Human Relations, Vol. 4 No. 1, pp. 3-38.

Tushman, M. and Nadler, D. (1986), "Organizing for innovation", California Management Review, Vol. 28 No. 3, pp. 74-92.

Tushman, M.L. and Anderson, P. (1986), "Technological discontinuities and organizational environments", Administrative Science Quarterly, Vol. 31 No. 3, pp. 439-465.

von Bertalanffy, L. (1969), "The theory of open systems in physics and biology”, System Thinking, Vol. 111 No. 2872, pp. 83-99.

Wang, J., Solan, D. and Ghods, A. (2010), "Distance learning success - a perspective from socio-technical systems theory”, Behaviour \& Information Technology, Vol. 29 No. 3, pp. 321-329.

Watson, J.G. and Rao Korukonda, A. (1995), “The TQM jungle: a dialectical analysis”, International Journal of Quality \& Reliability Management, Vol. 12 No. 9, pp. 100-109.

Wei, W.C. (2010), "From mediate and moderate view to untangle the relationship among product innovation performance, cross-functional cooperation and quality practices", International Journal of Information and Management Sciences, Vol. 21 No. 4, pp. 365-389.

Wilkinson, A. (1992), "The other side of quality: 'soft' issues and the human resource dimension”, Total Quality Management, Vol. 3 No. 3, pp. 323-330.

Wind, J. and Mahajan, V. (1997), "Editorial: issues and opportunities in new product development: an introduction to the special issue", Journal of Marketing Research, Vol. 34 No. 1, pp. 1-12.

Wu, S.-I.I. and Chen, J.H.H. (2011), "Comparison between manufacturing companies that are ISO certified and those that are not certified using performance measurement model", Total Quality Management \& Business Excellence, Vol. 22 No. 8, pp. 869-890.

Wu, L.W., Lii, Y. S. and Wang, C.Y. (2015), "Managing innovation through co-production in interfirm partnering", Journal of Business Research, Vol. 68 No. 11, pp. 2248-2253.

Yahya, S. and Goh, W.-K. (2001), "The implementation of an ISO 9000 quality system”, International Journal of Quality \& Reliability Management, Vol. 18 No. 9, pp. 941-966.

Yusr, M.M., Mokhtar, S.S.M., Othman, A.R. and Sulaiman, Y. (2017), "Does interaction between TQM practices and knowledge management processes enhance the innovation performance?", International Journal of Quality \& Reliability Management, Vol. 34 No. 7, pp. 955-974. 
Zeng, J., Anh Phan, C. and Matsui, Y. (2015), "The impact of hard and soft quality management on quality and innovation performance: an empirical study", International Journal of Production Economics, Vol. 162, pp. 216-226.

Zeng, J., Zhang, W., Matsui, Y. and Zhao, X. (2017), "The impact of organizational context on hard and soft quality management and innovation performance", International Journal of Production Economics, Vol. 185, pp. 240-251.

Ziegler, A. (2015), "Disentangling technological innovations: a micro-econometric analysis of their determinants", Journal of Environmental Planning and Management, Vol. 58 No. 2, pp. 315-335.

$\mathrm{Zu}, \mathrm{X}$. (2009), "Infrastructure and core quality management practices: how do they affect quality?", International Journal of Quality \& Reliability Management, Vol. 26 No. 2, pp. 129-149.

\section{Corresponding author}

Younès El Manzani can be contacted at: younes.elmanzani@gmail.com 